\title{
Anthropogenic Nitrate Pollution in Groundwater and Its Health Risks in The View of Background Concentration in a Semi-Arid Area of Rajasthan
}

\author{
Abdur Rahman ( $\sim$ alrahman777@gmail.com ) \\ National Geophysical Research Institute \\ N.C. Mondal \\ National Geophysical Research Institute \\ K.K. Tiwari \\ National Institute of Technology (NIT), Garhwal, Uttarakhand, India
}

\section{Research Article}

Keywords: Hydrochemistry, nitrate pollution, natural background, anthropogenic impacts, health risk assessment, semi-arid area, Rajasthan

Posted Date: January 20th, 2021

DOl: https://doi.org/10.21203/rs.3.rs-147468/v1

License: (9) This work is licensed under a Creative Commons Attribution 4.0 International License. Read Full License

Version of Record: A version of this preprint was published at Scientific Reports on April 29th, 2021. See the published version at https://doi.org/10.1038/s41598-021-88600-1. 


\title{
Anthropogenic nitrate pollution in groundwater and its health risks in the view of background concentration in a semi-arid area of Rajasthan
}

\author{
Abdur Rahman ${ }^{\mathrm{a}, \mathrm{b}^{*}}$, N.C. Mondal ${ }^{\mathrm{a}, \mathrm{b}}$ and K.K. Tiwari ${ }^{\mathrm{c}}$

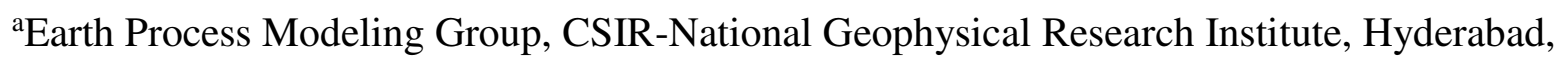 \\ India \\ ${ }^{\mathrm{b}}$ Academy of Scientific \& Innovative Research (AcSIR), Ghaziabad - 201 002, India \\ ${ }^{\mathrm{c}}$ National Institute of Technology (NIT), Garhwal, Uttarakhand, India \\ *Corresponding author: alrahman@ngri.res.in
}

\section{Abstract}

An increased nitrate $\left(\mathrm{NO}_{3}{ }^{-}\right)$concentration in groundwater has been a rising issue on a global scale in recent years. Through different consumption mechanisms, it clearly illustrates the adverse effects on human health. The goal of this present study is to assess the natural and anthropogenic $\mathrm{NO}_{3}{ }^{-}$concentration in groundwater and its related risks to human health in the different groups of ages such as children, males, and females. Groundwater samples $(n=101)$ were obtained and analysed for their physicochemical components, along with the nitrate concentration in a semi-arid area of Rajasthan. The results show that most of the samples were influenced by anthropogenic activities. The background and anthropogenic levels had been estimated and marked as $7.2 \mathrm{mg} / \mathrm{L}$ and $13.3 \mathrm{mg} / \mathrm{L}$ for the background and anthropogenic concentrations, respectively. About $83 \%$ of nitrate samples were exceeded the background limit, while $28 \%$ of the samples were beyond the permissible limit of $45 \mathrm{mg} / \mathrm{L}$ as stated by the Bureau of Indian Standards (BIS). Nitrate health risks were also measured by oral intake and dermal contact sources for the residents in this area. The oral exposure of nitrate was very high as compare to dermal contact. With regards to the non-carcinogenic health risk, the total Heath Index $\left(\mathrm{HI}_{\text {Total }}\right)$ values of groundwater nitrate in the study area varied from 0.045 to 3.153 with an average of 0.964 for males, 0.053 to 3.726 with an average of 1.139 for 
females, and 0.061 to 4.278 with an average of 1.308 for children. The nitrate health risk assessment shows that about $38 \%, 46 \%$, and $49 \%$ of groundwater samples constitute the noncarcinogenic health risk to males, females, and children, respectively.

Key words: Hydrochemistry, nitrate pollution, natural background, anthropogenic impacts, health risk assessment, semi-arid area, Rajasthan.

\section{Introduction}

Groundwater, especially in arid and semi-arid regions, is typically the most valuable water resource, and so the conservation of groundwater supplies is important worldwide ${ }^{1}$. However, over the past few decades, groundwater quality in most aquifers worldwide has declined due to increased human effects. The continued growth of the global population is inextricably related to an increase in the generation of waste ${ }^{2,3}$. Such waste, including domestic waste, waste from building and construction, chemical and toxic waste, sludge, and $\operatorname{ash}^{4}$. In this modern era, however, rapid development, population explosion, urbanisation, industrialization, tremendous use of fertilisers in irrigation fields, improper sewage systems, human and animal waste contribute to groundwater pollution ${ }^{5}$. Groundwater pollution is closely correlated with diffuse (non-point) sources for agricultural operations. Several types of inorganic and organic fertilisers are used ${ }^{6,7,8}$. The risk of groundwater pollution is raised by the improper use of chemicals and fertilisers. Once the groundwater is polluted, remediation is difficult. Thus, the prevention of pollution is also the key water quality control policy ${ }^{9}$. The primary source of inorganic nitrogen within the soil is nitrate, which is necessary for healthy crops to grow and develop ${ }^{10}$.

Nitrate $\left(\mathrm{NO}_{3}{ }^{-}\right)$is an enormously powerful environmental pollutant that not only arises naturally, but also released by a number of anthropogenic exercises. These anthropogenic activities include the manufacture and use of nitrate fertilizers, fossil fuel combustion (occur 
as atmospheric deposition, hereinafter $\mathrm{AD}$ ) and releases of both domestic and industrial sewage systems and modification in nitrogen-fixing crops in natural vegetation ${ }^{11-13}$. In most natural waters, nitrate forms a critical portion of the ionic charge. Because of the harmful effects on humans at high doses, $\mathrm{NO}_{3}{ }^{-}$ions are used in international regulations and guidelines $^{14}$. However, the long-term intake of elevated nitrate concentrations can cause serious health hazards in children, such as methemoglobinemia, which is also known as a blue baby syndrome, and stomach cancer in adults as well ${ }^{15,16}$. In view of this, the World Health Organisation (WHO) has defined a maximum nitrate level of a contaminant in drinking water as $50 \mathrm{mg} / \mathrm{L}$. As per the Indian situation, $45 \mathrm{mg} / \mathrm{L}$ is recommended by the Bureau of Indian Standards (BIS) as the permissible level of $\mathrm{NO}_{3}{ }^{-}$in drinking water. As a result of the prolonged ingestion of groundwater nitrate, serious health issues are encountered in the different parts of the world. Thus, nitrate exposure-related health risk assessment research is extensively studied in different countries such as China ${ }^{17-20}$, Pakistan ${ }^{21}, \operatorname{Iran}^{22,23}$, Mexico $^{24}$ and India ${ }^{5,25-27}$ have based on the non-carcinogenic risk between adults and children.

Usually, background levels are estimated either temporally (concentrations before anthropogenic activity) or spatially (concentrations in the areas not influenced by anthropogenic activity $)^{28}$. It may be difficult to establish background concentrations for certain pollutants, mainly those that have several and non-point sources or are environmentally reactive. Nitrate $\left(\mathrm{NO}_{3}{ }^{-}\right)$is an example of an ion for which it is difficult to establish a threshold concentration due to its different geogenic and anthropogenic origins and its reaction ${ }^{28,29}$. The issues with establishing a nitrate $\left(\mathrm{NO}_{3}{ }^{-}\right)$threshold value, is that natural or geogenic processes will differ greatly in time and space that influences $\mathrm{NO}_{3}-\mathrm{N}$ concentrations. It is generally found that $\mathrm{NO}_{3}-\mathrm{N}$ concentrations in aquifers decrease with down gradation or with depth ${ }^{28,30}$. If the groundwater reaches at redoxcline depth (redox 
boundary), where nitrate and oxygen suddenly vanish due to denitrification, this will occur within a relatively slight difference in depth ${ }^{31,32}$. These redox boundaries can shift with time, and there may be a limit to how much $\mathrm{NO}_{3}{ }^{-}$can be reduced in some aquifers, mainly those with low concentration organic carbon and ferric iron ${ }^{33}$. Thus an important aspect influencing the determination of background concentrations is the well depth from which groundwater samples are taken. The $\mathrm{NO}_{3}-\mathrm{N}$ concentrations can also be influenced by the water mixing of different ages and/or from different origin. Mixing can takes place naturally (e.g., due to quick recharge) or anthropogenically (e.g., due to construction of the well, wells are frequently uncased over greater depth). Other significant variables include lithology, soil composition, the thickness of unsaturated zone, and bioactivities ${ }^{28}$.

The investigated area falls under the arid and semi-arid climate state Rajasthan where the only source of fresh water is groundwater. According to the CGWB report ${ }^{34}$, most of the areas of the state have been categorised as over-exploitation zones. Along with the overexploitation of groundwater, the quality of this precious resource is also highly degraded. Thus, the key objectives of this research are: to (1) analyse groundwater chemistry, (2) evaluate regional natural background concentration of nitrate, (3) investigate nitrate toxicity for understanding the potential source and contamination mechanism of nitrate, and (4) quantify the potential non-carcinogenic health risk induced by groundwater exposure to nitrate using recommended model of the US Environmental Protection Agency ${ }^{35,36}$. To our knowledge, this is the first study of health risk assessment considering the natural background level of $\mathrm{NO}_{3}^{-}$in groundwater. The findings of this analysis will provide an important scientific and logical understanding of the human health risk of $\mathrm{NO}_{3}{ }^{-}$in groundwater and they will also lead to improve the levels of water quality.

\section{Material and Methods}


Study area. The area falls between $26^{\circ} 22^{\prime} 13.32^{\prime \prime}$ to $27^{\circ} 14^{\prime} 33.58^{\prime \prime}$ north latitudes and $76^{\circ}$ $08^{\prime} 32.62^{\prime \prime}$ to $77^{\circ} 05^{\prime} 00.41^{\prime \prime}$ east longitudes, covering an area of about $3420 \mathrm{~km}^{2}$ (Fig.1a).

Three significant river basins are present in the study area; Banganga basin (covering about $63 \%$ of the study area in the northern part), Morel basin (covering about $34 \%$ of area in the southern part), and a small part by Ghambhir basin (around 3\% of the area in the south of Mahwa) ${ }^{37}$. Agriculture production is scattered over both kharif, and rabi cultivation in the area; kharif cultivation is based on precipitation (rainfed) and rabi cultivation is especially based on groundwater source.

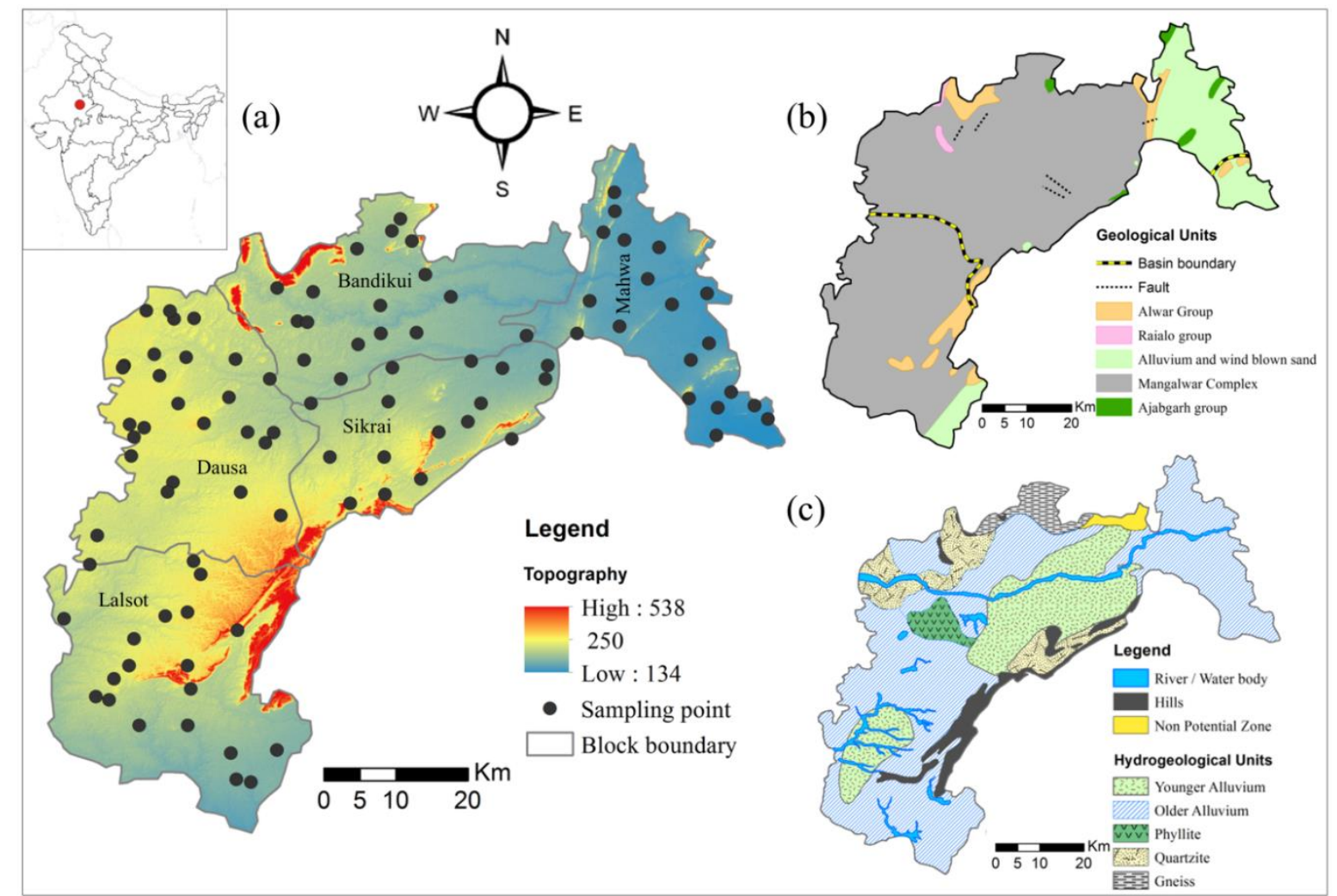

Figure 1. Showing the maps of (a) Topography in meters above mean sea level and the sampling location of Dausa district, Rajasthan, India, (b) regional geology, and (c) hydrogeology with the potential aquifers

114 Because of significant daily temperature variations and low, moderate rainfall, the climate of the area can be categorized as semi-arid. It is markedly seasonal and is characterised by a dry 
and steadily increasing hot season between March and May, a dry and cold winter between

117 October and February, but from June to September a monsoon season. In the study region, the minimum and maximum temperatures reported are below $10{ }^{\circ} \mathrm{C}$ in January, and $48{ }^{\circ} \mathrm{C}$ in June. The gross annual evapotranspiration potential is $1744.7 \mathrm{~mm}^{34}$.

Geology and Hydrogeology. In the study area, the Alwar group of rocks consists of quartzite and schist, alluvium and wind-blown sand occupied the north-eastern and southwestern parts (Fig.1b). The $3 / 4^{\text {th }}$ portion of the study area is covered by quaternary alluvium (Younger alluvium: $21.6 \%$, and older alluvium: $~ 58.4 \%$ ) consisting of Aeolian and fluvial slits, sand, gravel, and occasional pebbles ${ }^{37}$. In hard rock settings, the weathered, fractured, and jointed hard rocks form aquifers. Quartzite contributes to approximately $9 \%$ of the aquifer, gneisses and phyllite aquifers occupy $5.3 \%$ of the remaining Quaternary alluvium is the primary water-bearing a formation covering about $84.65 \%$ of the area $^{34}$. Talus and scree deposits and hard rocks of Bhilwara and Delhi Super Group rest in a small portion forming about $15.35 \%$ of the minor aquifers. Alluvium sediments including sand, and kankar (calcareous detrital materials), clay, and gravel forms the potential aquifer in the study area (Fig.1c). The occurrence of groundwater is marked under unconfined to confined aquifer conditions with the primary porosity of alluvium ${ }^{38}$.

The data used for this study. For assessing nitrate contamination and background criteria, analytical hydrochemical data collected by the State Groundwater Department Jaipur, Rajasthan. The samples were collected in $1.0 \mathrm{~L}$ polyethylene bottles and used for the analysis of major ions. Before collecting groundwater samples, the wells were drained for a sufficient time so that the accumulated water, if any, was absolutely removed from storage within the assembly of the well. As defined by the American Public Health Association ${ }^{39}$, the ions were analysed by the standard methods. The portable kits such as electrical conductivity (EC) and 
$141 \mathrm{Ca}^{2+}, \mathrm{Mg}^{2+}, \mathrm{Cl}^{-}, \mathrm{SO}_{4}{ }^{2-}, \mathrm{HCO}_{3}{ }^{-}$and $\left.\mathrm{NO}_{3}{ }^{-}\right)$and total hardness (TH) at Regional Chemical

142 Laboratory, Ground Water Department, Jaipur, Rajasthan. After verifying the reliability of 143 data, about 97 samples, out of 101 collected data were used for background analysis and 144 hydrochemical characterization. Furthermore, 37 samples were picked based on $11 \times 11 \mathrm{Km}$ 145 equal grid distribution and used for non-carcinogenic human health risk assessment.

146 Charge balance error. In order to verify the validity and reliability of the analysed hydrochemical dataset, the cation-anion balance procedure was carried out. The basic law of electro-neutrality allows the number of cations to be equal to or almost equal to the number of anions. The error was measured using the methods implemented ${ }^{40}$ to validate and remove low-quality samples. The ion concentration unit was first changed from milligram per litre $(\mathrm{mg} / \mathrm{L})$ to milliequivalent per litre $(\mathrm{meq} / \mathrm{L})$. To calculate the ionic balance error of each sample, the following given formula was used ${ }^{41,42}$.

$$
\text { Charge balance error }=\left\{\frac{\left(\sum \text { Cations }-\sum \text { Anions }\right)}{\left(\sum \text { Cations }+\sum \text { Anions }\right)}\right\} \times 100
$$

The calculation of groundwater quality results may good if the charge balance error is $< \pm$ $5 \%$, and if the charge balance error is $< \pm 5 \%$, it will be considered as poor ${ }^{43}$. However, the charge balance error of up to $\pm 10 \%$ is acceptable for groundwater ${ }^{44}$. The value would not pass the validation test if it is greater than \pm 10 . Among the 101 collected samples, four presented an error of more than $\pm 10 \%$, and three of them presented an error of more than 5 $\%$. About 97 samples, out of 101, fell within the $10 \%$ charge balance errors, which were considered reliable in this research work.

Natural background. Anthropogenic additions above background concentration from the numerous sources of nitrate are now a global issue. Additionally, it can be difficult to determine the background concentration of a specific chemical component. The criteria for identification of anthropogenic contamination had been adopted by using the probability 
distribution of random datasets. As a brief way of picking separate population as events in hydrogeochemical databases of a given chemical species, the cumulative probability (CP) approach has been introduced ${ }^{45}$. This method is quick and convenient for identifying the different population with the help of inflection point ${ }^{28,46-49}$ without any type of pre-selection of data. In the lack of long-term temporal databases, this method gives more reliable outcomes $^{49}$.

Shapiro-Wilk test was used to test the normality assumption of the different populations of the datasets. The SPSS statistics package programme was utilised to do all the statistical analysis (SPSS software, IBM SPSS product version 20 at $\mathrm{P}<0.05$ ). A value of $\mathrm{P}<0.05$ had been measured as statistically significant in all data analyses.

Health risk assessment. In general, the intake of polluted groundwater can cause a severe threat to humans, primarily by two exposure routes, first one is the ingestion of drinking water or oral route, and the second one is the dermal interaction route ${ }^{25,50}$. The US Environmental Protection Agency originally proposed this rigorous model for the assessment of human health risk ${ }^{35,36}$. In this study, the risk assessment was carried out in three groups of the exposed population, including children, females, and males.

where, in equation (2), CDI is referred as chronic daily intake (in $\mathrm{mg} / \mathrm{kg} / \mathrm{day}$ ); " $\mathrm{C}$ " is the concentration of groundwater nitrate (in $\mathrm{mg} / \mathrm{L}$ ); IR is denoted for daily ingestion rate of groundwater (in L/day) for both males and females ingestion rate is $2.5 \mathrm{~L} /$ day and for children, ingestion rate is $1 \mathrm{~L} /$ day ${ }^{35}$; EF is denoted for the exposure frequency (in days/year), 
and the exposure frequency is considered as 365 days/year for males, females, and children $^{35}$; ED is denoted for exposure duration (in a year), for children 12 years, for females 67 years, and for males, 64 years have considered for this study ${ }^{25,27}$; ABW is the average body weight as $65 \mathrm{~kg}, 55 \mathrm{~kg}$, and $15 \mathrm{~kg}$ for males, females, and children, respectively. The mean exposure time (days) for AET is 23360 days, 24455 days, and 4380 days for males, females, and children, respectively. In equation (3), the hazard quotient is presented as HQ. RfD indicates reference dose of nitrate contaminant (in $\mathrm{mg} / \mathrm{kg} /$ day) which is 1.6 $\mathrm{mg} / \mathrm{kg} / \mathrm{day}^{35,36}$.

196

197

The non-carcinogenic health risk from dermal contact is calculated by the following formulas $^{5,17,18,51}$ :

$$
D A D=\frac{C \times T C \times K_{i} \times C F \times E V \times E D \times E F \times S S A}{A B W \times A E T}
$$

$$
H Q_{\text {Dermal }}=\frac{D A D}{R f D}
$$

$$
H I_{\text {Total }}=\sum_{i=1}^{n}\left(H Q_{\text {oral }}+H Q_{\text {Dermal }}\right)
$$

where, in equation (4) DAD indicates the dermal absorbed dose (in $\mathrm{mg} / \mathrm{kg} \times$ day); TC is the contact time (in $\mathrm{h} /$ day) taken as $0.4 \mathrm{in} \mathrm{h} /$ day; $\mathrm{Ki}$ represents the dermal adsorption parameters (in $\mathrm{cm} / \mathrm{h}$ ) taken as $0.001 \mathrm{~cm} / \mathrm{h}$; and $\mathrm{CF}$ is denoted for conversion factor taken as $0.001^{36,52}$. EV represents bathing frequency (in times/day), and the bathing frequency is considered as one time in a day, and SSA indicates the skin surface area (in $\mathrm{cm}^{2}$ ) and values for SSA are taken as 16,600 sq. centimetres for both males and females, and 12,000 sq. centimetres for children ${ }^{36,52}$. In equation (6), HI is the hazard index, and non-carcinogenic human health risk is denoted by the value of HI. The HI value greater than one shows the potential human health risk from nitrate contamination, and HI value less than one expresses an acceptable level of health risk on human ${ }^{36,52}$. 
Data treatment. Descriptive statistics were carried out using SPSS 25.0, and the sample concentration results were compared with the Indian Standard of drinking water quality ${ }^{53}$. We performed principal component analysis (PCA), a commonly used statistical tool for extracting critical knowledge from multivariate data, based on the correlation coefficients ${ }^{54,55}$. ArcGIS 10.3 software (ESRI, Redlands, California, USA) and Surfer 13 were used to make distribution maps and interpolate the experimental dataset.

\section{Results and discussion}

Hydrochemical examination. The detailed statistics of hydrochemical parameters and their drinking limits suggested by the Bureau of Indian Standards ${ }^{53}$ for groundwater quality are presented in Table 1 . The electrical conductivity (EC) values of groundwater varied between 290 and $3800 \mu \mathrm{S} / \mathrm{cm}$, with the mean value of $1430.5 \mu \mathrm{S} / \mathrm{cm}$. The $\mathrm{pH}$ value ranged from 8.1 to 9.3 , with a mean value of 8.8 , indicating the groundwater is alkaline in nature. An important characteristic factor, parenting dissolved chemical concentrations, was the total dissolved solids (TDS) values. The TDS value varied between $158.4 \mathrm{mg} / \mathrm{l}$ and 2182.5 , with the mean value of $820.9 \mathrm{mg} / \mathrm{L}$. The hydrochemical analysis indicates that about $70 \%$ of the samples had been exceeded the drinking limits of the BIS guidelines ${ }^{53}$ in the context of the TDS values. Among cations, $\mathrm{Na}^{+}$was observed predominant, followed by $\mathrm{Mg}^{2+}>\mathrm{Ca}^{2+}>\mathrm{K}^{+}$based on average cation concentrations. Among anions, $\mathrm{HCO}_{3}{ }^{-}$was observed as the predominant anion, followed by $\mathrm{Cl}^{-}>\mathrm{SO}_{4}{ }^{2-}>\mathrm{CO}_{3}{ }^{-}>\mathrm{NO}_{3}{ }^{-}>\mathrm{F}^{-}$. Bicarbonate was the key component of all largely dissolved groundwater ions in the study area. High concentrations of $\mathrm{HCO}_{3}{ }^{-}$were found and ranged from 61.0 to $817.7 \mathrm{mg} / \mathrm{L}$, with the mean value of $336.8 \mathrm{mg} / \mathrm{L}$. The elevated concentration of $\mathrm{Cl}^{-}$was observed, and it ranges 21.3 to $1049.3 \mathrm{mg} / \mathrm{L}$, with an average of $186.1 \mathrm{mg} / \mathrm{L}$. The spatial distribution of hydrochemical 
parameters has shown in Fig. S1. The elevated level of $\mathrm{Cl}^{-}$was noticed in the northern central, and southern parts of the study area (Fig. S1). The northern portion and the western side of the study area were the zones where EC was high in the groundwater (Fig.S1). The result indicates around $28 \%$ of groundwater samples of $\mathrm{NO}_{3}{ }^{-}$were beyond the BIS limit, however, spatial distribution had shown (Fig. 5d) that the elevated concentrations of $\mathrm{NO}_{3}{ }^{-}$ were located especially in the northern, central and southern. The heterogeneous distribution of the hydrochemical variables in groundwater also indicates the discrepancy

242 in the coefficient of variance (CV\%) values. The CV of several hydrochemical parameters $\left(\mathrm{K}^{+}, \mathrm{SO}_{4}{ }^{2-}, \mathrm{NO}_{3}{ }^{-}, \mathrm{Cl}^{-}\right.$, and $\left.\mathrm{F}^{-}\right)$in groundwater is more than 100 percent in terms of variance coefficient $(\mathrm{CV})$, as shown in Table1. Very High CV of $\mathrm{K}^{+}(532.64 \%)$, $\mathrm{SO}_{4}{ }^{2-}(222.55 \%), \mathrm{NO}_{3}^{-}(170.37 \%)$ and $\mathrm{Cl}^{-}(139.58 \%)$ demonstrate the potential pollution by anthropogenic activities in the study area.

Table 1. Statistics of groundwater quality parameters and the exceeding percentage of each parameter based on the BIS guidelines (2012)

\begin{tabular}{|c|c|c|c|c|c|c|c|c|}
\hline Parameters & Min. & Max. & Mean & SD & Median & $\mathrm{CV} \%$ & $\begin{array}{l}\text { BIS Standard, } \\
2012\end{array}$ & $\begin{array}{l}\text { Sample exceeding } \\
\text { BIS guidelines }(\%)\end{array}$ \\
\hline $\mathrm{pH}$ & 8.1 & 9.3 & 8.8 & 0.26 & 8.8 & 3.02 & $6.5-8.5$ & 86 \\
\hline $\mathrm{EC}(\mathrm{mS} / \mathrm{cm})$ & 290.0 & 3800.0 & 1430.5 & 844.12 & 1200.0 & 70.34 & 1500 & 46 \\
\hline TDS (mg/L) & 158.4 & 2182.5 & 820.9 & 505.95 & 687.0 & 73.64 & 500 & 70 \\
\hline $\mathrm{Na}^{+} \quad(\mathrm{mg} / \mathrm{L})$ & 15.2 & 733.4 & 244.7 & 177.85 & 223.0 & 79.75 & 200 & 57 \\
\hline $\mathrm{K}^{+} \quad(\mathrm{mg} / \mathrm{L})$ & 0.8 & 129.0 & 8.3 & 20.83 & 3.9 & 532.64 & -- & -- \\
\hline $\mathrm{Ca}^{2+} \quad(\mathrm{mg} / \mathrm{L})$ & 4.0 & 36.1 & 12.6 & 6.69 & 12.0 & 55.68 & 75 & -- \\
\hline $\mathrm{Mg}^{2+}(\mathrm{mg} / \mathrm{L})$ & 12.2 & 144.7 & 39.7 & 25.56 & 32.8 & 77.84 & 30 & 86 \\
\hline $\mathrm{Cl}^{-} \quad(\mathrm{mg} / \mathrm{L})$ & 21.3 & 1049.3 & 186.1 & 188.03 & 134.7 & 139.58 & 250 & 27 \\
\hline $\mathrm{SO}_{4}{ }^{2-}(\mathrm{mg} / \mathrm{L})$ & 19.2 & 422.7 & 87.3 & 90.86 & 40.8 & 222.55 & 200 & 5 \\
\hline $\mathrm{CO}_{3^{-}}^{-}(\mathrm{mg} / \mathrm{L})$ & 24.0 & 144.2 & 64.4 & 32.64 & 60.1 & 54.32 & -- & -- \\
\hline $\mathrm{HCO}_{3}{ }^{-}(\mathrm{mg} / \mathrm{L})$ & 61.0 & 817.7 & 336.8 & 182.23 & 244.1 & 74.66 & 200 & 73 \\
\hline $\mathrm{NO}_{3}^{-}(\mathrm{mg} / \mathrm{L})$ & 1.2 & 151.3 & 34.3 & 36.97 & 21.7 & 170.37 & 45 & 28 \\
\hline $\mathrm{F}^{-} \quad(\mathrm{mg} / \mathrm{L})$ & 0.2 & 4.8 & 1.2 & 0.99 & 1.0 & 102.84 & 1 & 37 \\
\hline TH $\quad(\mathrm{mg} / \mathrm{L})$ & 80.0 & 650.0 & 194.7 & 107.21 & 170.0 & 63.07 & 200 & 32 \\
\hline
\end{tabular}


254 Background Level of Nitrate. The majority of published $\mathrm{NO}_{3}{ }^{-}$concentrations have been 255 described as suggesting anthropogenic groundwater contamination, which was estimated by different techniques. The background concentration of nitrate in groundwater had been estimated using a statistical approach. In which the cumulative probability method was used to separate different population events of nitrate in groundwater. The background concentrations and anthropogenic concentrations of nitrate had been marked with a sharp inflection point at $9.3 \mathrm{mg} / \mathrm{L}$ (Fig. 2a). Then the natural background level (NBL) and anthropogenic level (APL) were calculated as $90^{\text {th }}$ percentile $(7.2 \mathrm{mg} / \mathrm{L})$ and $10^{\text {th }}$ percentile $(13.3 \mathrm{mg} / \mathrm{L})$ of the events separated by inflection point, respectively. Probability density curves with respect to the nitrate concentration of distinct populations (NBL, APL, and original) have been shown in Fig.2b.

The Shapiro-Wilk test was used (in Table S1) to test the normality of different populations (NBL and APL). If the Shapiro-Wilk test significance value is greater than 0.05 , the data is normal. If it is smaller than 0.05 , the data will deviate greatly from the normal distribution. In this test, the significance value of NBL was obtained as 0.072 , which indicated the normality of NBL, while the significance value of APL and original concentrations of nitrate indicated abnormality. Thus this test strengthens and supports the background value of nitrate in the groundwater of the study area. The background concentration of nitrate was high compared to other works related to the nitrate background ${ }^{28}$. This high level of background concentration may have affected by anthropogenic factors ${ }^{48}$. However, the spatial distribution of NBL along total concentration of nitrate is shown in Fig. 5d. This figure illustrates that the variation between NBL and the experimental concentration of $\mathrm{NO}_{3}{ }^{-}$was high in the northern, central, and southern parts of the study area. The same areas were marked as potential health risk threats for adults and children. 
278

279

280

281

282

283

284

285

286

287

288

289

290

291

292

293
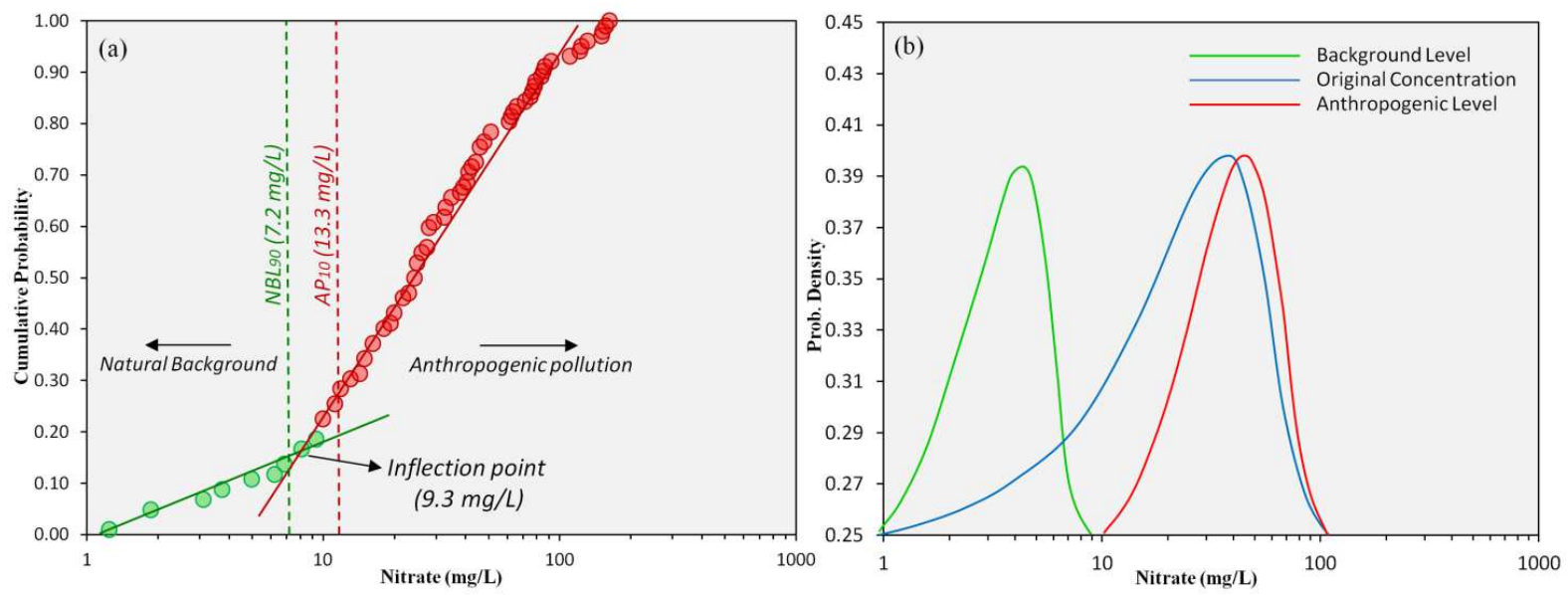

Figure 2. Showing (a) Cumulative probability plots of the $\mathrm{NO}_{3}{ }^{-}$concentration in groundwater on which two normal subpopulations events (estimated NBL; natural background level, and APL; anthropogenic level). In each plot, a single inflection point is observed on log-scale, and (b) Probability density curve of a distinct population of $\mathrm{NO}_{3}^{-}$concentration in groundwaters

Nitrate distribution and mechanism of contamination. Groundwater nitrate vulnerability can be described as the sensitivity of an aquifer's susceptibility to nitrate contamination, based on the redox environment in both the aquifer material and the overlying geological strata $^{56,57}$. In groundwater, the presence of nitrate is due to various sources and origins. Nitrate pollution happens in several environments for different causes, viz. septic tank leakage, fertilisers used in farm fields, landfill leachate, leakage of sewerage pipes, drainage of poultry waste, and household / cultivation of animal dung ${ }^{51,58-60}$. There are many approaches that can apply to the overall nitrate concentration of ordinary groundwater, such as geological characteristics, environments, anthropogenic activities, nitrogen-bearing soil, and atmospheric nitrogen fixation ${ }^{61}$. The disparity in $\mathrm{NO}_{3}{ }^{-}$content in various inspection areas may be due to cyclical precipitation, the energy rate of subsurface water, mechanism of evapotranspiration, and so on ${ }^{62-64}$. Nitrate is usually quickly dissolved in surface water and readily enters the groundwater as well. In addition, an oxidising state in the landfill site may 
also cause a nitrification reaction that normally converts ammonia $\left(\mathrm{NH}_{3}\right)$ to nitrate $\left(\mathrm{NO}_{3}{ }^{-}\right)$, and hence also raises nitrate concentration in the groundwater ${ }^{5,24,65,66}$. The following equation can be understood as the whole nitrification mechanism ${ }^{67}$.

$$
\mathrm{NH}_{4}+2 \mathrm{O}_{2} \rightarrow \mathrm{NO}_{3}^{-}+\mathrm{H}_{2} \mathrm{O}+2 \mathrm{H}^{+}
$$

The box plots in Fig. 3, demonstrates the chronological change (in time series) in nitrate concentrations in Dausa's groundwater over the past 8 years (2011 to 2018). The study area does not display any distinct temporal shift in nitrate concentrations except in 2018, where the highest groundwater sample exceeded the BIS drinking limit was about $28 \%$. Usually, bivariate plots, $\mathrm{NO}_{3}{ }^{-}$versus $\mathrm{K}^{+}$, and $\mathrm{NO}_{3}^{-}$versus $\mathrm{Cl}^{-}$are commonly used to classify the possible causes of nitrate contamination ${ }^{5,68-70}$. The positive correlation between $\mathrm{NO}_{3}{ }^{-}$and $\mathrm{K}^{+}$ (Fig. 4a) indicated that elevated nitrate might derive from the non-point sources (including fertilizers, manure, and sewage), which cause anthropogenic pollution above the background concentration. A good correlation between $\mathrm{NO}_{3}{ }^{-}$and $\mathrm{Cl}^{-}$was noted in the study area (Fig. 4b). It also indicated that groundwater nitrate was may be due to the sources of animal and human waste from these ions. A researcher ${ }^{71}$ claimed that an increase in chloride concentration with an increase in nitrate was mainly due to the septic tank.

In general, principal component analysis (PCA) is widely utilized to describe the relationship between parameters of water quality and their probable source determination. In this analysis, three principal components (PCs) were generated by transformation of hydrochemical parameters including $\mathrm{pH}, \mathrm{TDS}, \mathrm{K}^{+}, \mathrm{Na}^{+}, \mathrm{Mg}^{2+}, \mathrm{Ca}^{2+}, \mathrm{Cl}^{-}, \mathrm{SO}_{4}{ }^{2-}, \mathrm{HCO}_{3}{ }^{-}$and $\mathrm{NO}_{3}{ }^{-}$) adopting Varimax orthogonal rotation and Kaiser normalisation. These PCs were examined with eigenvalues greater than one (Fig. S2) and their total variance at 48.288\%, $19.943 \%$, and $11.539 \%$, respectively, with the cumulative variance of $79.77 \%$ (Table 2). The high and moderate positive loadings of EC (0.942), TDS (0.933), $\mathrm{Na}^{+}(0.859), \mathrm{Cl}^{-}(0.927)$ and $\mathrm{SO}_{4}{ }^{2-}$ 
323 (0.862) were observed with $\mathrm{PC} 1$. This suggests that high $\mathrm{NO}_{3}{ }^{-}$in the groundwater may derive

324 from several anthropogenic sources, including fertilisers, septic tanks, domestic sewage,

325 animal waste, and wastewater ${ }^{66}$. The PC3 show high positive loadings of $\mathrm{K}^{+}(0.838)$ and

$326 \mathrm{NO}_{3}{ }^{-}(0.867)$, signifying that the source of nitrate in the groundwater was not the same as

327 other ions. This indicates the source of elevated nitrate may come from anthropogenic activities but not from river waters ${ }^{66}$. The study area is dominated by agricultural land, followed by build-up areas. This scenario of the study area itself justifies that the possible source of groundwater nitrate was agricultural inputs or domestic sewage.

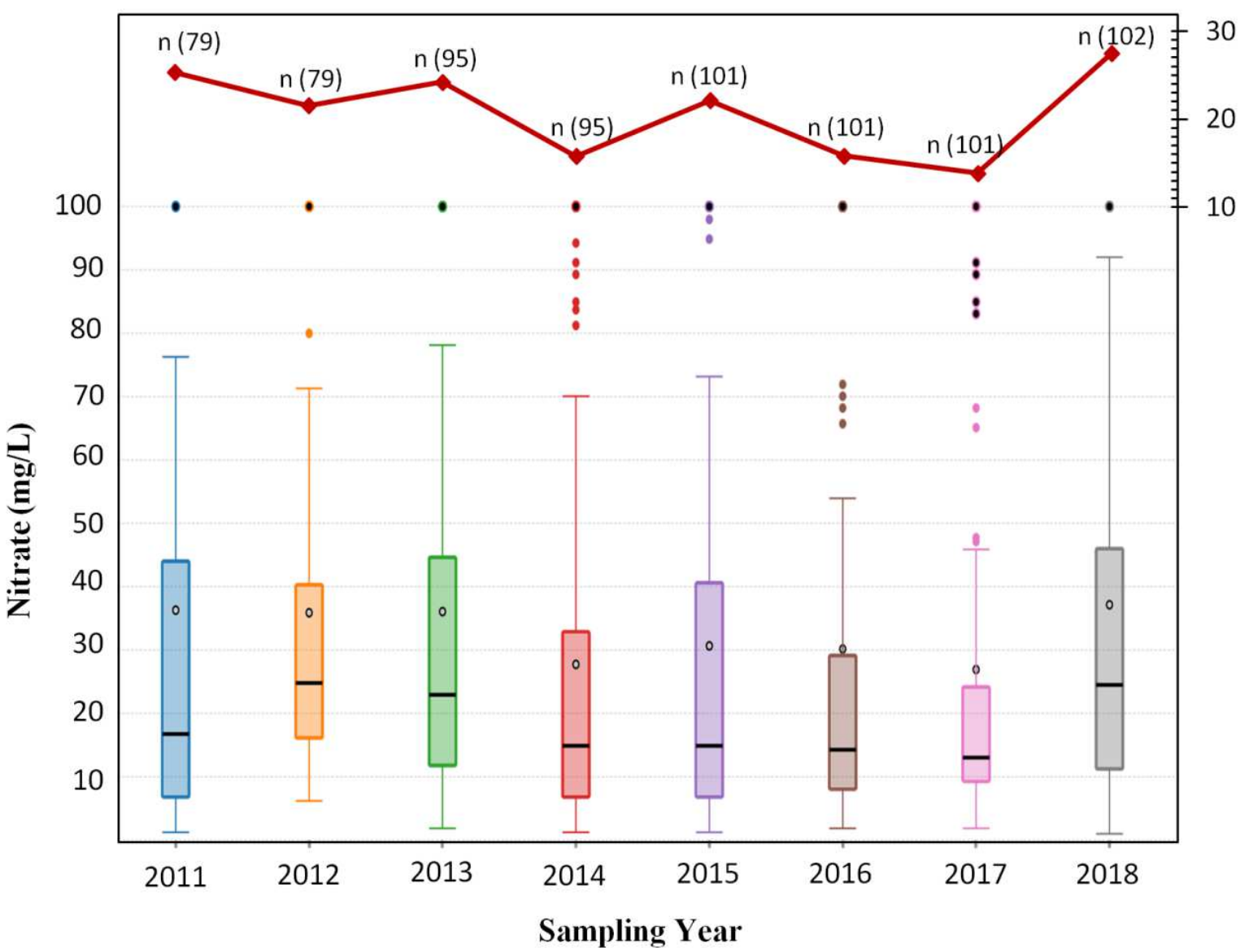

Figure 3. Showing the temporal changes of nitrate concentrations during 8 years (2011-2018)

334 in groundwater of the study area. The red lines above the Box and Whisker plots illustrate the percentage of samples beyond the Indian drinking water standards $(45 \mathrm{mg} / \mathrm{L})$ and ' $\mathrm{n}$ ' denoted as the number of groundwater samples 

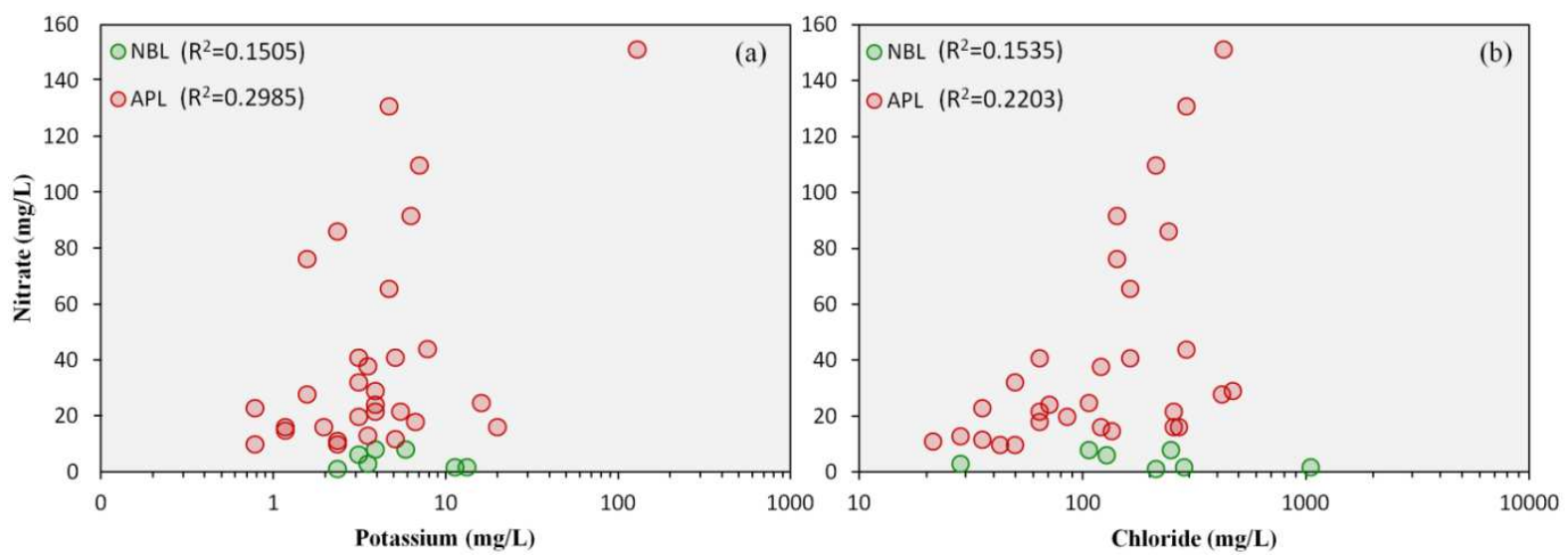

Figure 4. Scatter plots showing the relationship between (a) nitrate and potassium, and (b) nitrate and chloride

Table 2. Significant principal components (PCs) loading for hydrochemical parameters in the study area

\begin{tabular}{|c|c|c|c|c|c|c|c|}
\hline \multirow[b]{2}{*}{ Component } & \multicolumn{3}{|c|}{ Initial Eigenvalues } & \multicolumn{3}{|l|}{ Component } & \multirow[b]{2}{*}{ PC3 } \\
\hline & Total & $\%$ of Variance & $\begin{array}{l}\text { Cumulative } \\
\%\end{array}$ & Parameters & PC1 & $\mathrm{PC} 2$ & \\
\hline 1 & 5.312 & 48.288 & 48.288 & $\mathrm{pH}$ & -0.062 & 0.800 & -0.045 \\
\hline 2 & 2.194 & 19.943 & 68.231 & $\mathrm{EC}$ & 0.942 & 0.264 & 0.189 \\
\hline 3 & 1.269 & 11.539 & 79.771 & TDS & 0.933 & 0.270 & 0.226 \\
\hline 4 & 0.898 & 8.164 & 87.934 & $\mathrm{Na}^{+}$ & 0.859 & 0.490 & 0.070 \\
\hline 5 & 0.574 & 5.221 & 93.155 & $\mathrm{~K}^{+}$ & 0.165 & -0.145 & 0.838 \\
\hline 6 & 0.397 & 3.606 & 96.760 & $\mathrm{Ca}^{2+}$ & -0.114 & -0.427 & 0.031 \\
\hline 7 & 0.213 & 1.936 & 98.696 & $\mathrm{Mg}^{2+}$ & 0.641 & -0.571 & 0.296 \\
\hline 8 & 0.135 & 1.229 & 99.925 & $\mathrm{Cl}^{-}$ & 0.927 & -0.254 & 0.048 \\
\hline 9 & 0.007 & 0.064 & 99.989 & $\mathrm{SO}_{4}^{2-}$ & 0.862 & 0.128 & 0.189 \\
\hline 10 & 0.001 & 0.008 & 99.997 & $\mathrm{HCO}_{3}^{-}$ & 0.369 & 0.834 & 0.200 \\
\hline 11 & 0.000 & 0.003 & 100.000 & $\mathrm{NO}_{3}^{-}$ & 0.162 & 0.123 & 0.867 \\
\hline
\end{tabular}



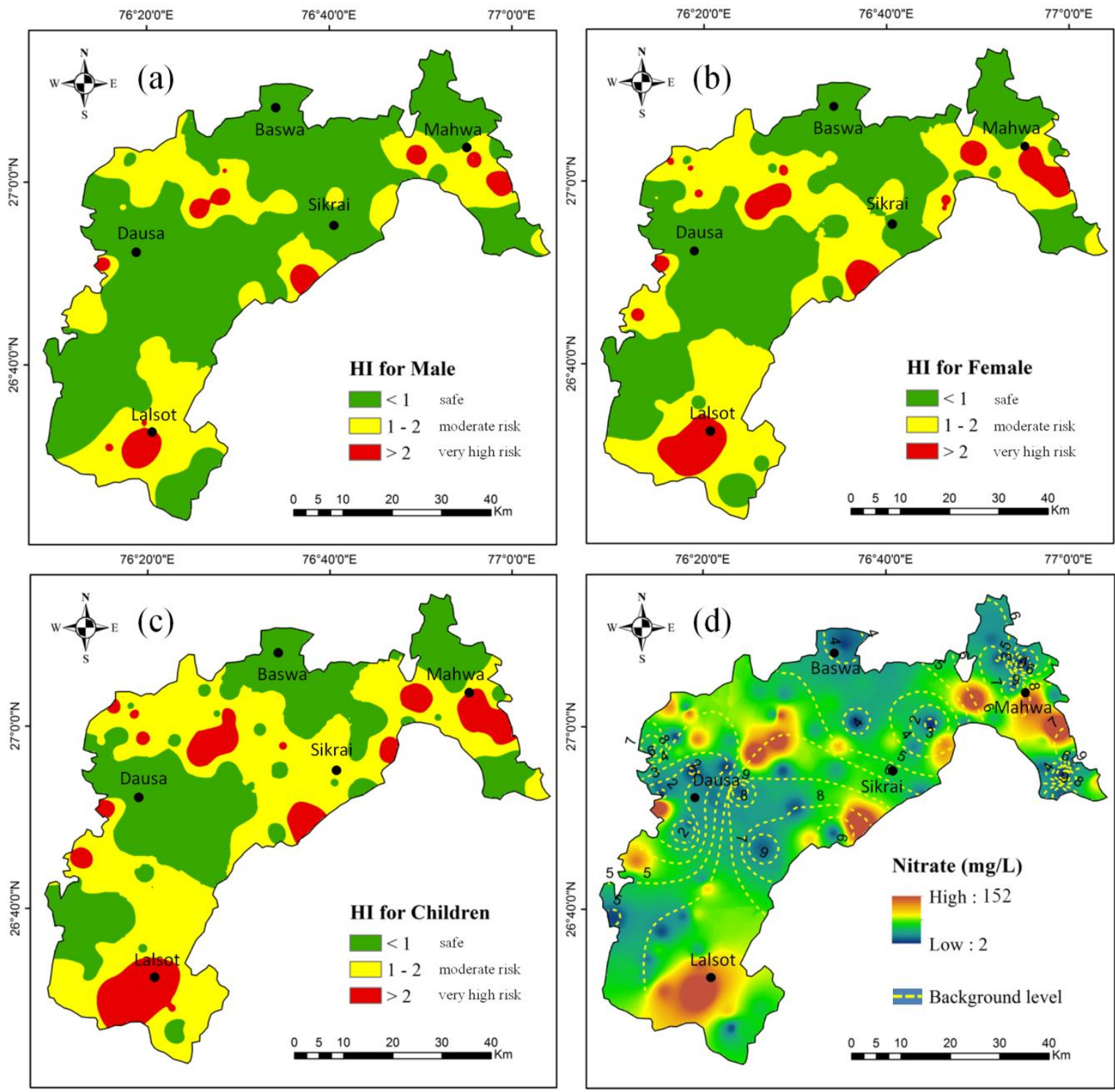

Figure 5. Showing spatial distribution of non-carcinogenic health risks for (a) Hazard Index (HI) of males, (b) Hazard Index (HI) of females, (c) Hazard Index (HI) of children in the study area, and

(d) spatial distribution of nitrate concentration and its background concentrations with the contour lines 
357 Table 3. Summary of the estimated non-carcinogenic risks of Nitrate ingestion of drinking 358 water and dermal exposure

\begin{tabular}{|c|c|c|c|c|c|c|c|c|c|}
\hline \multirow{2}{*}{ Sample } & \multicolumn{3}{|l|}{ HQ Oral } & \multicolumn{3}{|c|}{ HQ Dermal } & \multicolumn{3}{|l|}{$\mathrm{HI}_{\text {Total }}$} \\
\hline & Males & Females & Children & Males & Females & Children & Males & Females & Children \\
\hline W-1 & 0.581 & 0.687 & 0.786 & 0.002 & 0.002 & 0.005 & 0.583 & 0.689 & 0.791 \\
\hline $\mathrm{W}-2$ & 0.358 & 0.423 & 0.484 & 0.001 & 0.001 & 0.003 & 0.359 & 0.424 & 0.487 \\
\hline W-3 & 0.909 & 1.074 & 1.229 & 0.002 & 0.003 & 0.008 & 0.912 & 1.077 & 1.237 \\
\hline W-4 & 2.638 & 3.118 & 3.567 & 0.007 & 0.008 & 0.022 & 2.645 & 3.126 & 3.588 \\
\hline W-5 & 2.206 & 2.607 & 2.982 & 0.006 & 0.007 & 0.018 & 2.212 & 2.614 & 3.001 \\
\hline W-6 & 0.388 & 0.458 & 0.524 & 0.001 & 0.001 & 0.003 & 0.389 & 0.459 & 0.527 \\
\hline $\mathrm{W}-7$ & 0.388 & 0.458 & 0.524 & 0.001 & 0.001 & 0.003 & 0.389 & 0.459 & 0.527 \\
\hline $\mathrm{W}-8$ & 1.103 & 1.303 & 1.491 & 0.003 & 0.003 & 0.009 & 1.106 & 1.307 & 1.500 \\
\hline W-9 & 1.058 & 1.251 & 1.431 & 0.003 & 0.003 & 0.009 & 1.061 & 1.254 & 1.439 \\
\hline $\mathrm{W}-10$ & 1.803 & 2.131 & 2.438 & 0.005 & 0.006 & 0.015 & 1.808 & 2.137 & 2.453 \\
\hline W-11 & 0.581 & 0.687 & 0.786 & 0.002 & 0.002 & 0.005 & 0.583 & 0.689 & 0.791 \\
\hline W-12 & 0.238 & 0.282 & 0.322 & 0.001 & 0.001 & 0.002 & 0.239 & 0.283 & 0.324 \\
\hline W-13 & 0.522 & 0.616 & 0.705 & 0.001 & 0.002 & 0.004 & 0.523 & 0.618 & 0.710 \\
\hline W-14 & 0.164 & 0.194 & 0.222 & 0.000 & 0.001 & 0.001 & 0.164 & 0.194 & 0.223 \\
\hline $\mathrm{W}-15$ & 1.520 & 1.797 & 2.055 & 0.004 & 0.005 & 0.013 & 1.524 & 1.801 & 2.068 \\
\hline W-16 & 1.103 & 1.303 & 1.491 & 0.003 & 0.003 & 0.009 & 1.106 & 1.307 & 1.500 \\
\hline W-17 & 2.042 & 2.413 & 2.761 & 0.005 & 0.006 & 0.017 & 2.047 & 2.419 & 2.778 \\
\hline W-18 & 0.775 & 0.916 & 1.048 & 0.002 & 0.002 & 0.006 & 0.777 & 0.918 & 1.054 \\
\hline W-19 & 0.477 & 0.564 & 0.645 & 0.001 & 0.001 & 0.004 & 0.478 & 0.565 & 0.649 \\
\hline W-20 & 0.522 & 0.616 & 0.705 & 0.001 & 0.002 & 0.004 & 0.523 & 0.618 & 0.710 \\
\hline W-21 & 0.626 & 0.740 & 0.846 & 0.002 & 0.002 & 0.005 & 0.628 & 0.742 & 0.852 \\
\hline W-22 & 1.893 & 2.237 & 2.559 & 0.005 & 0.006 & 0.016 & 1.898 & 2.243 & 2.575 \\
\hline $\mathrm{W}-23$ & 3.145 & 3.716 & 4.252 & 0.008 & 0.010 & 0.026 & 3.153 & 3.726 & 4.278 \\
\hline W-24 & 0.268 & 0.317 & 0.363 & 0.001 & 0.001 & 0.002 & 0.269 & 0.318 & 0.365 \\
\hline $\mathrm{W}-25$ & 0.238 & 0.282 & 0.322 & 0.001 & 0.001 & 0.002 & 0.239 & 0.283 & 0.324 \\
\hline W-26 & 1.103 & 1.303 & 1.491 & 0.003 & 0.003 & 0.009 & 1.106 & 1.307 & 1.500 \\
\hline W-27 & 0.581 & 0.687 & 0.786 & 0.002 & 0.002 & 0.005 & 0.583 & 0.689 & 0.791 \\
\hline W-28 & 0.045 & 0.053 & 0.060 & 0.000 & 0.000 & 0.000 & 0.045 & 0.053 & 0.061 \\
\hline W-29 & 0.238 & 0.282 & 0.322 & 0.001 & 0.001 & 0.002 & 0.239 & 0.283 & 0.324 \\
\hline W-30 & 0.522 & 0.616 & 0.705 & 0.001 & 0.002 & 0.004 & 0.523 & 0.618 & 0.710 \\
\hline W-31 & 0.671 & 0.793 & 0.907 & 0.002 & 0.002 & 0.006 & 0.672 & 0.795 & 0.912 \\
\hline W-32 & 0.551 & 0.652 & 0.746 & 0.001 & 0.002 & 0.005 & 0.553 & 0.653 & 0.750 \\
\hline W-33 & 0.939 & 1.110 & 1.269 & 0.002 & 0.003 & 0.008 & 0.941 & 1.113 & 1.277 \\
\hline W-34 & 0.984 & 1.163 & 1.330 & 0.003 & 0.003 & 0.008 & 0.986 & 1.166 & 1.338 \\
\hline W-35 & 1.222 & 1.444 & 1.652 & 0.003 & 0.004 & 0.010 & 1.225 & 1.448 & 1.662 \\
\hline W-36 & 1.461 & 1.726 & 1.975 & 0.004 & 0.005 & 0.012 & 1.464 & 1.731 & 1.987 \\
\hline W-37 & 1.714 & 2.026 & 2.317 & 0.005 & 0.005 & 0.014 & 1.718 & 2.031 & 2.332 \\
\hline Min. & 0.045 & 0.053 & 0.060 & 0.000 & 0.000 & 0.000 & 0.045 & 0.053 & 0.061 \\
\hline Max. & 3.145 & 3.716 & 4.252 & 0.008 & 0.010 & 0.026 & 3.153 & 3.726 & 4.278 \\
\hline Mean & 0.961 & 1.136 & 1.300 & 0.003 & 0.003 & 0.008 & 0.964 & 1.139 & 1.308 \\
\hline
\end{tabular}


Health risk assessment (Non-carcinogenic). Health risk assessment including males, females, and children had been done based on the guidelines of the United State Environmental Protection Agency ${ }^{35,52}$, and the calculated results are shown in Table 3. Health risk (Hazard Index-HI) spatial distribution maps for males, females and children were also produced and are shown in Fig. 5. For three different age classes, the findings of HQDermal were slightly lower than zero, while HQ Oral ranged from 0.045 to 3.145 with an average of 0.961 for males, 0.053 to 3.716 with an average of 1.136 for females, and 0.060 to 4.252 with an average of 1.300 for children (Table 3). The results show that the exposure of nitrate directly due to drinking water ingestion was higher than the exposure due to dermal interactions in the study area. The reasonable limit for non-carcinogenic health risk is $\leq 1$ (HI $\leq 1)$, based on the USEPA health risk standards. If the hazard index $(\mathrm{HI})$ value is $>1$, then the possibility of an adverse risk to human health is very high ${ }^{52}$. $\mathrm{HI}_{\text {Total }}$ values in the study area are varied from 0.045 to 3.153 (average: 0.964 ) for males, 0.053 to 3.726 (average: 1.139 ) for females and 0.061 to 4.278 (average: 1.308) for children (Table 3). Out of 37 groundwater samples, 14 samples for males, 17 samples for females, and 18 samples for infants, the nitrate exposure levels in drinking water were found to expose these age groups to serious nitrate problems. More importantly, the findings appear to suggest that children are more vulnerable to non-carcinogenic effects in the study region owing to the intake of higher nitrate concentrations in drinking water. Many other scholars have found that due to lower body weight and personality characteristics, children are more vulnerable to chronic noncarcinogenic threats than adults ${ }^{5,72-76}$.

The non-carcinogenic hazard index (HI) map (as shown in Fig. 5) clearly indicates that the northern, central, and southern parts of the study area have higher health risk zones for males, females, and children. Especially it can be noticed that the area of health risk due to groundwater nitrate is high for children as compared to the adults (Fig. 5c). As is visible from 
Fig.5a,b,c, there is no detrimental impact of a non-carcinogenic risk on the visible green colour in the spatial distribution of hazard index in the study area, although the yellow and red regions show that population in these areas pose potential health threats in the study area. It indicates that the areas of yellow and red zones were in danger due to higher HI values; these areas were not recommended for direct intake of drinking water. The spatial distribution of the background values of nitrate (Fig.5d) showed that the health hazard was high at the place where the significant difference between NBL and total concentrations of groundwater nitrate was noticed. Excessive nitrate intake through groundwater can result in adverse biological problems, such as methemoglobinemia, which is also known as blue baby many parts of the globe where a significant populace depends entirely on groundwater resources for drinking without pre-examination of safety problems, the non-carcinogenic health risk of $\mathrm{NO}_{3}{ }^{-}$in drinking water becomes a serious issue $20,66,77,78,80,81$. In northern India, a detailed study done $\mathrm{e}^{73}$ and assessed the human health risk of nitrate. Their research found about $36 \%$ of samples demonstrated greater non-carcinogenic health issues on children due to higher content of nitrate in groundwater, signifying a tremendous risk to human health of nitrate. Similarly, in southern India, a researcher ${ }^{5}$ had analysed the issues due to groundwater nitrate. Their findings reveal that about $60 \%, 57 \%$, and $50 \%$ of groundwater samples were in 407 the range of potential health risk for children, females, and males, respectively. Likewise, 408 another study related to nitrate health implications was carried ${ }^{82}$ in the northern Shandong Peninsula of China, and found that about $87.6 \%$ of water samples were unfit for nitrate concentration-based consumption. The findings of their analysis also indicate that health hazards are more dangerous to infants and children due to nitrate ingestion via oral and 
412 dermal exposure pathways. Thus, owing to the drinking of contaminated groundwater, the 413 intensity of health risk steadily increases.

414 Recommendation for drinking water resource management. Both natural and anthropogenic mechanisms regulated the consistency of groundwater during the experimental period. In certain regions, because of abnormal natural environments and long-term anthropogenic factors, as we noticed in Dausa district, Rajasthan, India, the concentration of contaminants, especially nitrate, could be increased from other regions. In general, groundwater contamination has only been measured by taking into account the drinking water requirements for the entire region or the whole country. The consideration of NBL in health risk assessment will be a crucial parameter for a better understanding of geogenic and anthropogenic contamination of any chemical parameter in the groundwater environment. However, as a result of the current study, it is indeed recommended that the local government urgently takes the requisite steps to reduce groundwater nitrate pollution and also ensures the availability of clean drinking water in the affected areas of the study area.

\section{Conclusions}

Hydrochemical data were analysed to assess the background concentration of nitrate and possible health risks due to the elevated concentration in the drinking water of Dausa district, Rajasthan, India. The natural background concentration (NBL) of groundwater nitrate is estimated using a statistical approach. In which firstly cumulative probability approach is used to separate the distinct population. Then normality of the individual population is checked by the Shapiro-Wilk test. The estimated NBL of nitrate is $7.2 \mathrm{mg} / \mathrm{L}$ in the study area; above this background concentration, anthropogenically added nitrate is responsible for the high concentration in groundwater. The main sources of nitrate in groundwater environments with concentrations above background concentrations are agricultural fertiliser, and human 
and animal wastes. In this analysis, principal components (PCs) are generated by the

437 processing hydrochemical parameters using Varimax orthogonal rotation and Kaiser

438

439

440

441 Normalisation. The high and moderate positive loadings of EC, TDS, $\mathrm{Na}^{+}, \mathrm{Cl}^{-}$and $\mathrm{SO}_{4}{ }^{2-}$ are observed with the $\mathrm{PC} 1$. This suggests that high $\mathrm{NO}_{3}{ }^{-}$in the groundwater may derive from several anthropogenic sources.

The health risk assessment, including males, females, and children has been done based on the guidelines of the United State Environmental Protection Agency, and also calculated. For the non-carcinogenic risk, the values of the total hazard index $\left(\mathrm{HI}_{\text {Total }}\right)$ in the study area are varied from 0.045 to 3.153 (average: 0.964 ) for males, 0.053 to 3.726 (average: 1.139 ) for females, and 0.061 to 4.278 (average: 1.308 ) for children. The result has clearly indicated that Children in the study area are more vulnerable to health hazards than women and men. The spatial distribution of nitrate background values has also revealed that the health hazard is high at the places where the significant difference between NBL and total nitrate concentrations in groundwater has been noticed. Thus the consideration of NBL in health risk assessment will be a crucial parameter for a better understanding of geogenic and anthropogenic contaminations of any chemical parameter in the groundwater environment.

\section{CRediT authorship contribution statement}

Abdur Rahman: Conceptualized, processed, analysed and interpreted the data, and drafted the original manuscript. N.C. Mondal: Conceptualized, designed the research works, revised critically and significantly to improve the article. K.K. Tiwari: Acquired the analytical data.

\section{Acknowledgments}

Director of CSIR-NGRI, Hyderabad, Dr. V.M. Tiwari has permitted to publish this article (Ref. No.: NGRI/Lib/2021/pub-09). State Ground Water Department, Rajasthan has helped to 


\section{References}

1. Jia, X. et al. Groundwater depletion and contamination: Spatial distribution of groundwater resources sustainability in China. Sci. Total Environ. 672, 551-562 (2019).

2. USEPA. Municipal solid waste generation, recycling and disposal in United Sates. United States Environmental Protection Agency, Washington, DC, pp. 01-14 20460 (EPA-530-F-14-001) (2012).

3. NEA. Nature and Environment - Waste Accounts. The Norwegian Environment Agency (http://www.environment.no/Topics/Waste/ or http://www.ssb.no/en/ natur-ogmiljo/statistikker/avfregno 12/08/2016, 19:23 PM) (2016).

4. Abiriga, D., Vestgarden, L. S., \& Klempe, H. Groundwater contamination from a municipal landfill: Effect of age, landfill closure, and season on groundwater chemistry. Sci. Total Environ. 737, 140307 (2020).

5. Adimalla, N., Qian, H. Groundwater chemistry, distribution and potential health risk appraisal of nitrate enriched groundwater: A case study from the semi-urban region of South India. Ecotoxicol Environ Saf. 207, 111277 (2021).

6. Scanlon, B.R., Jolly, I., Sophocleous, M., Zhang, L. Global impacts of conversions from natural to agricultural ecosystems on water resources: quantity versus quality. Water Resour. Res. 43, W03437 (2007).

7. Sebilo, M., Mayer, B., Nicolardot, B., Pinay, G., Mariotti, A. Long-term fate of nitrate fertilizer in agricultural soils. Proc. Natl. Acad. Sci. U. S. A. 110, 18185-18189 (2013).

8. Kim, K. H., Yun, S. T., Kim, H. K., \& Kim, J. W. Determination of natural backgrounds and thresholds of nitrate in South Korean groundwater using model-based statistical approaches. J. Geochem. Explor. 148, 196-205 (2015).

9. Ceplecha, Z.L., Waskom, R.M., Bauder, T.A., Sharkoff, J.L., Khosla, R. Vulnerability assessments of Colorado ground water to nitrate contamination. Water Air Soil Pollut. 159, 373-394 (2004).

10. Pisciotta, A., Cusimano, G., Favara, R. Groundwater nitrate risk assessment using intrinsic vulnerability methods: A comparative study of environmental impact by intensive farming in the Mediterranean region of Sicily, Italy. J. Geochem. Explor. 156, 89-100 (2015). 
11. Gutiérrez, M., Biagioni, R.N., Alarcón-Herrera, M.T., Rivas-Lucero, B.A. An overview of nitrate sources and operating processes in arid and semiarid aquifer systems. Sci. Total Environ. 624, 1513-1522 (2018).

12. Ward, M. et al. Drinking water nitrate and human health: an updated review. Int. J. Environ. Res. Public Health 15, 1557 (2018).

13. Torres-Martínez, J.A. et al. Estimation of nitrate pollution sources and transformations in groundwater of an intensive livestock-agricultural area (Comarca Lagunera), combining major ions, stable isotopes and MixSIAR model, Environ. Pollut. 269, 115445 (2020).

14. Torres-Martínez, J. A., Mora, A., Knappett, P., Ornelas-Soto, N., \& Mahlknecht, J. Tracking nitrate and sulfate sources in groundwater of an urbanized valley using a multi-tracer approach combined with a Bayesian isotope mixing model. Water Res. 182, 115962 (2020).

15. Datta, P.S., Deb, D.L., Tyagi, S.K. Assessment of groundwater contamination from fertilizers in the Delhi area based on 180, $\mathrm{NO}_{3}{ }^{-}$and $\mathrm{K}^{+}$composition. J. Contam. Hydrol. 27 (3), 249-262 (1997).

16. WHO. Guidelines for drinking water quality: fourth edition incorporating the first addendum. World Health Organization, Geneva (2017).

17. Chen, J., Qian, H., Wu, H. Nitrogen contamination in groundwater in an agricultural region along the New Silk Road, northwest China: distribution and factors controlling its fate. Environ. Sci. Pollut. Res. 24 (15), 13154-13167 (2017).

18. Chen, J., Wu, H., Qian, H., Gao, Y. Assessing nitrate and fluoride contaminants in drinking water and their health risk of rural residents living in a semiarid region of northwest China. Exposure Health 9 (3), 183-195 (2017).

19. Su, H., Kang, W., Xu, Y., Wang, J. Assessing groundwater quality and health risks of nitrogen pollution in the Shenfu mining area of Shaanxi province, northwest China. Exposure Health $\mathbf{1 0}$ (2), 77-97 (2018).

20. Gao, S., et al. Health risk assessment of groundwater nitrate contamination: a case study of a typical karst hydrogeological unit in East China. Environ. Sci. Pollut. Res. 27 (9), 9274-9287 (2020).

21. Rehman, J.U., Ahmad, N., Ullah, N., Alam, I., Ullah, H. Health risks in different age group of nitrate in spring water used for drinking in Harnai, Balochistan, Pakistan. Ecol. Food Nutr. 1$10(2020)$.

22. Qasemi, M. et al. Health risk assessments due to nitrate levels in drinking water in villages of Azadshahr, northeastern Iran. Environ. Earth Sci. 77 (23), 782 (2018).

23. Yousefi, M., Ghoochani, M., Hossein Mahvi, A. Health risk assessment to fluoride in drinking water of rural residents living in the Poldasht city, Northwest of Iran. Ecotoxicol. Environ. Saf. 148, 426-430 (2018).

24. P'erez Villarreal, J., Avila ' Olivera, J.A., Israde Alcantara, ' I., Buenrostro Delgado, O. Nitrate as a parameter for differentiating groundwater flow systems in urban and agricultural areas: the case of Morelia-Capula area, Mexico. Hydrogeol. J. 27, 1767-1778 (2019). 
25. Adimalla, N. Controlling factors and mechanism of groundwater quality variation in semiarid region of South India: an approach of water quality index (WQI) and health risk assessment (HRA). Environ. Geochem. Health 42 (6), 1725-1752 (2020).

26. Adimalla, N., Li, P., Qian, H. Evaluation of groundwater contamination for fluoride and nitrate in semi-arid region of Nirmal Province, South India: a special emphasis on human health risk assessment (HHRA). Hum. Ecol. Risk Assess. 25 (5), 1107-1124 (2019).

27. Karunanidhi, D. et al. Evaluation of non-carcinogenic risks due to fluoride and nitrate contaminations in a groundwater of an urban part (Coimbatore region) of south India. Environ. Monit. Assess. 192 (2), 102 (2020).

28. Panno, S.V., Kelly, W.R., Martinsek, A.T., Hackley, K.C. Estimating background and threshold nitrate concentrations using probability graphs. Groundwater 44 (5), 697-709 (2006).

29. Panno, S.V., W.R. Kelly, C.P. Weibel, I.G. Krapac, and S.L. Sargent. Water quality and agrichemical loading in two groundwater basins of Illinois' sinkhole plain. Environmental Geology Series 156. Champaign, Illinois: Illinois State Geological Survey (2003).

30. Tomer, M.D., and M.R. Burkart. Long-term effects of nitrogen fertilizer use on ground water nitrate in two small watersheds. J. Environ. Qual. 32, 2158-2171 (2003).

31. Appelo, C.A.J., and D. Postma. Geochemistry, groundwater and pollution. Rotterdam, The Netherlands: A.A. Balkema (1994).

32. Kelly, W.R. Heterogeneities in ground-water geochemistry in a sand aquifer beneath an irrigated field. J Hydrol 198, 154-176 (1997).

33. Smedley, P.L., and W.M. Edmunds. Redox patterns and trace-element behaviour in the East Midlands Triassic sandstone aquifer, U.K. Ground Water 40, 44-58 (2002).

34. Central Groundwater Board CGWB. Groundwater Brochure Dausa District, Rajasthan. CGWBWR, Jaipur, p. 21 (2008).

35. USEPA. Risk assessment guidance for superfund, vol I., Human health evaluation manual (Part A) office of emergency and remedial response (1989).

37. Tiwari, K.K. et al. Evaluation of fluoride contamination in groundwater in a semi-arid region, Dausa District, Rajasthan, India. Groundw. 11, 100465 (2020).

36. USEPA. Exposure factors handbook, volume 1: General Factors. U. S, Environmental Protection Agency, office of research and development, Washington (1997).

38. Mondal, N., Tiwari, K., Sharma, K., \& Ahmed, S.,. A diagnosis of groundwater quality from a semiarid region in Rajasthan, India. Arab. J. Geosci, 9, 1-22 (2016)

39. American Public Health Association (APHA). standard methods for the examination of water and waste, sixteenth ed. Am Public Health Association, Washington DC, p. 100 (1985).

40. Feitosa, F.A.C., Manoel Filho, J., Feitosa, E.C., Demetrio, J.G.A. Hidrogeologia: conceitos e aplicaçoes (Hydrogeology: Concepts and Applications). CPRM, p. 812 (2008).

41. Freeze, R.A., Cherry, J.A. Groundwater. Prentice-Hall Inc., Englewood Cliffs, NJ, p. 97 (1979).

42. Hem, J.D. Study and interpretation of the chemical characteristics of natural water. United States Geological Survey Water-Supply Paper 2254, p. 165 (1985). 
43. Hounslow, Arthur W. Water quality data: analysis and interpretation. Lewis Publisher, CRC Press LLC, USA, pp. 49-73 (1995).

44. Katz Brian, G., Collins Jerilyn, J. Evaluation of chemical data from selected sites in the SurfaceWater Ambient Monitoring Program (SWAMP) in Florida. Open-File Report 98-559. USGS, p. 4 (1998).

45. Runnells, D D, Dupon, D P, Jones, R L, Cline, D J. Determination of background chemistry of water at mining and milling sites, Salt Lake Valley, Utah, USA. 997-1000 in Proceedings of the Water Rock Interaction. Proceedings of the 9th International Symposium on Water-Rock Interaction, Taupo, New Zealand, (Rotterdam: A A Balkema) (1998).

46. Mondal, N.C. Reconnoitering hydrochemical background using log-probability distribution in a Channel Island, Andhra Pradesh. In: $5^{\text {th }}$ National Conference Proceeding on Water, Environment \& Society, 271-277 (2018).

47. Mondal, N.C. Exploring hydrochemical backgrounds using cumulative probability approach for finding groundwater suitability in an industrial area from Peninsular India. J. Appl. Geochem. (in press) (2020).

48. Rahman, A., Tiwari. K.K., Mondal, N.C. Assessment of hydrochemical backgrounds and threshold values of groundwater in a part of desert area, Rajasthan, India. Environ. Pollut. 266 (3), 115150 (2020)

49. Rahman, A., Mondal, N. C., \& Fauzia, F. Arsenic enrichment and its natural background in groundwater at the proximity of active floodplains of Ganga River, northern India. Chemosphere, 265, 129096 (2021).

50. Adimalla, N., Qian, H. Groundwater quality evaluation using water quality index (WQI) for drinking purposes and human health risk (HHR) assessment in an agricultural region of Nanganur, south India. Ecotoxicol. Environ. Saf. 176, 153-161 (2019).

51. Karunanidhi, D., Aravinthasamy, P., Subramani, T., Wu, J., Srinivasamoorthy, K. Potential health risk assessment for fluoride and nitrate contamination in hard rock aquifers of Shanmuganadhi River basin, South India,Hum. Ecol. Risk Assess. 250-270 (2019).

52. USEPA. Supplemental guidance for developing soil screening levels for superfund sites. $U$. $S$. Environmental Protection Agency, office of emergency and remedial response, Washington (2002).

53. Bureau of Indian Standard (BIS). Indian Standards Specification for Drinking Water. IS: 10500: 2012, 2nd Rev. BIS, New Delhi (2012).

54. Zhang, X., Wei, S., Sun, Q., Wadood, S. A., Guo, B. Source identification and spatial distribution of arsenic and heavy metals in agricultural soil around Hunan industrial estate by positive matrix factorization model, principle components analysis and geo statistical analysis. Ecotoxicol. Environ. Saf. 159, 354-362 (2018).

55. Gu, C. et al. spatial distribution and health risk assessment of dissolved trace elements in groundwater in southern China. Sci Rep. 10, 7886 (2020).

56. Hansen, B. et al. Nitrate vulnerability assessment of aquifers. Environ Earth Sci 75, 999 (2016). 
57. Voutchkova, D.D., Schullehner,J., Rasmussen, P., Hansen, B. A high-resolution nitrate vulnerability assessment of sandy aquifers (DRASTIC-N). J. Environ. Manage. 277, 111330 (2021)

58. Mondal, N.C., Saxena, V.K., Singh, V.S. Occurrence of elevated nitrate in groundwaters of Krishna delta, India. Afr. J. Environ. Sci. Technol. 2 (9), 265-271 (2008).

59. Suthar, S. et al. Nitrate contamination in groundwater of some rural areas of Rajasthan, India. $J$ Hazard Mater 171, 189-199 (2009).

60. Abdesselam, S. et al. Anthropogenic contamination of groundwater with nitrate in arid region: case study of southern Hodna (Algeria). Environ Earth Sci. 70, 2129-41 (2013).

61. Khandare, H.W. Scenario of nitrate contamination in groundwater: its causes and prevention. Int J ChemTech Res 5, 1921-6 CODEN (USA): IJCRGG ISSN: 0974-4290 (2013).

62. Shalev, N., Burg, A., Gavrieli, I., and Lazar, B. Nitrate contamination sources in aquifers underlying cultivated fields in an arid region - the Arava Valley, Israel. Appl Geochem 63, 322-32 (2015).

63. Nakagawa, K. et al. On the use of coprostanol to identify source of nitrate pollution in groundwater. J Hydrol 550, 663-8 (2017).

64. Buvaneshwari, S. et al. Groundwater resource vulnerability and spatial variability of nitrate contamination: insights from high density tubewellmonitoring in a hard rock aquifer. Sci Total Environ 579, 838-47 (2017).

65. Stuart, M.E., Gooddy, D.C., Bloomfield, J.P., Williams, A.T. A review of the impact of climate change on future nitrate concentrations in groundwater of the UK. Sci. Total Environ. 409 (15), 2859-2873 (2011).

66. Zhang, M. et al. Distributions and origins of nitrate, nitrite, and ammonium in various aquifers in an urbanized coastal area, south China. J Hydrol 582, 124528 (2020).

67. Ahamad, A., Raju, N.J., Madhav, S., Gossel, W., Wycisk, P. Impact of nonengineered Bhalswa landfill on groundwater from Quaternary alluvium in Yamuna flood plain and potential human health risk, New Delhi, India. Quat. Int. 507, 352-369 (2019).

68. Sajil Kumar, P.J., Jegathambal, P. \& James, E.J. Chemometric evaluation of nitrate contamination in the groundwater of a hard rock area in Dharapuram, south India. Appl Water Sci 4, 397-405 (2014).

69. Zhang, Q., Sun, J., Liu, J., Huang, G., Lu, C., Zhang, Y. Driving mechanism and sources of groundwater nitrate contamination in the rapidly urbanized region of south China. J. Contam. Hydrol. 182, 221-230 (2015).

71. McQuillan D. Ground-water quality impacts from on-site septic systems. Proceedings, National Onsite Wastewater Recycling Association, 13th annual conference, Albuquerque, NM, 7-10, 13 (2004).

72. Li, Y. et al. Long term spatial-temporal dynamics of fluoride in sources of drinking water and associated health risks in a semiarid region of Northern China. Ecotoxicol. Environ. Saf. 171, 274-280 (2019). 
73. Ravindra, K., Thind, P.S., Mor, S., Singh, T., Mor, S. Evaluation of groundwater contamination in Chandigarh: source identification and health risk assessment. Environ. Pollut. 255, 113062 (2019).

74. Adimalla, N. Spatial distribution, exposure, and potential health risk assessment from nitrate in drinking water from semi-arid region of South India. Hum. Ecol. Risk Assess. 26 (2), 310-334 (2020).

75. Singh, G., Rishi, M.S., Herojeet, R., Kaur, L., Sharma, K. Evaluation of groundwater quality and human health risks from fluoride and nitrate in semi-arid region of northern India. Environ. Geochem. Health 42, 1833-1862 (2020).

76. Adimalla, N. Groundwater quality for drinking and irrigation purposes and potential health risks assessment: a case study from semi-arid region of South India. Exposure Health 11 (2), 109123 (2019).

77. Wick, K., Heumesser, C., Schmid, E. Groundwater nitrate contamination: factors and indicators. J. Environ. Manag. 111, 178-186 (2012).

78. Adimalla, N., Li, P. Occurrence, health risks, and geochemical mechanisms of fluoride and nitrate in groundwater of the rock-dominant semi-arid region, Telangana State, India. Hum. Ecol. Risk Assess. 25 (1-2), 81-103 (2019).

79. Narsimha, A., Rajitha, S. Spatial distribution and seasonal variation in fluoride enrichment in groundwater and its associated human health risk assessment in Telangana State, South India. Hum. Ecol. Risk Assess. 24 (8), 2119-2132 (2018).

80. Karyab, H., Hajimirmohammad-Ali, R., Bahojb, A. A lumped-parameter model for investigation of nitrate concentration in drinking water in arid and semi-arid climates and health risk assessment. J. Environ. Health Sci. Eng. 17, 457-465 (2019).

81. Cui, M., Zeng, L., Qin, W., Feng, J. Measures for reducing nitrate leaching in orchards: A review. Environ. Pollut. 263, 114553 (2020).

82. Wu, J., Lu, J., Wen, X., Zhang, Z., Lin, Y. Severe nitrate pollution and health risks of coastal

(1)

(1)

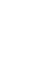

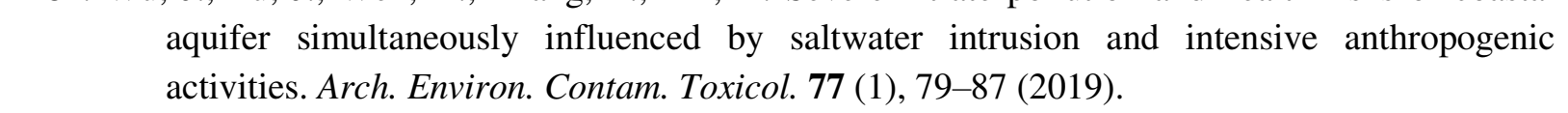




\section{Table Captions:}

688

689

690

691

692

693

694

695

696

697

698

699

700

701

702

703

704

705

706

707

708

709

710

711

712

Table 1. Statistics of groundwater quality parameters and the exceeding percentage of each parameter based on the BIS guidelines (2012)

Table 2. Significant principal components (PCs) loading for hydrochemical parameters in the study area

Table 3. Summary of the estimated non-carcinogenic risks of Nitrate ingestion of drinking water and dermal exposure

\section{Figure Captions:}

Figure 1. Showing the maps of (a) Topography in meters above mean sea level and the sampling location of Dausa district, Rajasthan, India, (b) regional geology, and (c) hydrogeology with the potential aquifers

Figure 2. Showing (a) Cumulative probability plots of the $\mathrm{NO}_{3}{ }^{-}$concentration in groundwater on which two normal subpopulations events (estimated NBL; natural background level, and APL; anthropogenic level). In each plot, a single inflection point is observed on log-scale, and (b) Probability density curve of a distinct population of $\mathrm{NO}_{3}^{-}$concentration in groundwaters

Figure 3. Showing the temporal changes of nitrate concentrations during 8 years (2011-2018) in groundwater of the study area. The red lines above the Box and Whisker plots illustrate the percentage of samples beyond the Indian drinking water standards $(45 \mathrm{mg} / \mathrm{L})$ and ' $\mathrm{n}$ ' denoted as the number of groundwater samples

Figure 4. Scatter plots showing the relationship between (a) nitrate and potassium, and (b) nitrate and chloride

Figure 5. Showing spatial distribution of non-carcinogenic health risks for (a) Hazard Index (HI) of males, (b) Hazard Index (HI) of females, (c) Hazard Index (HI) of children in the 
714 concentrations with the contour lines

715

716 Suppl. Table Captions:

717 Table S1. Normality test of distinguished population

718

719 Suppl. Figure Captions:

720 Figure S1. Spatial distribution of hydrochemical parameters in a semi-arid area, Rajasthan,

721 India

722 Figure S2. Scree plot for principal component analysis showing 3 components with >1

723 Eigenvalues value 


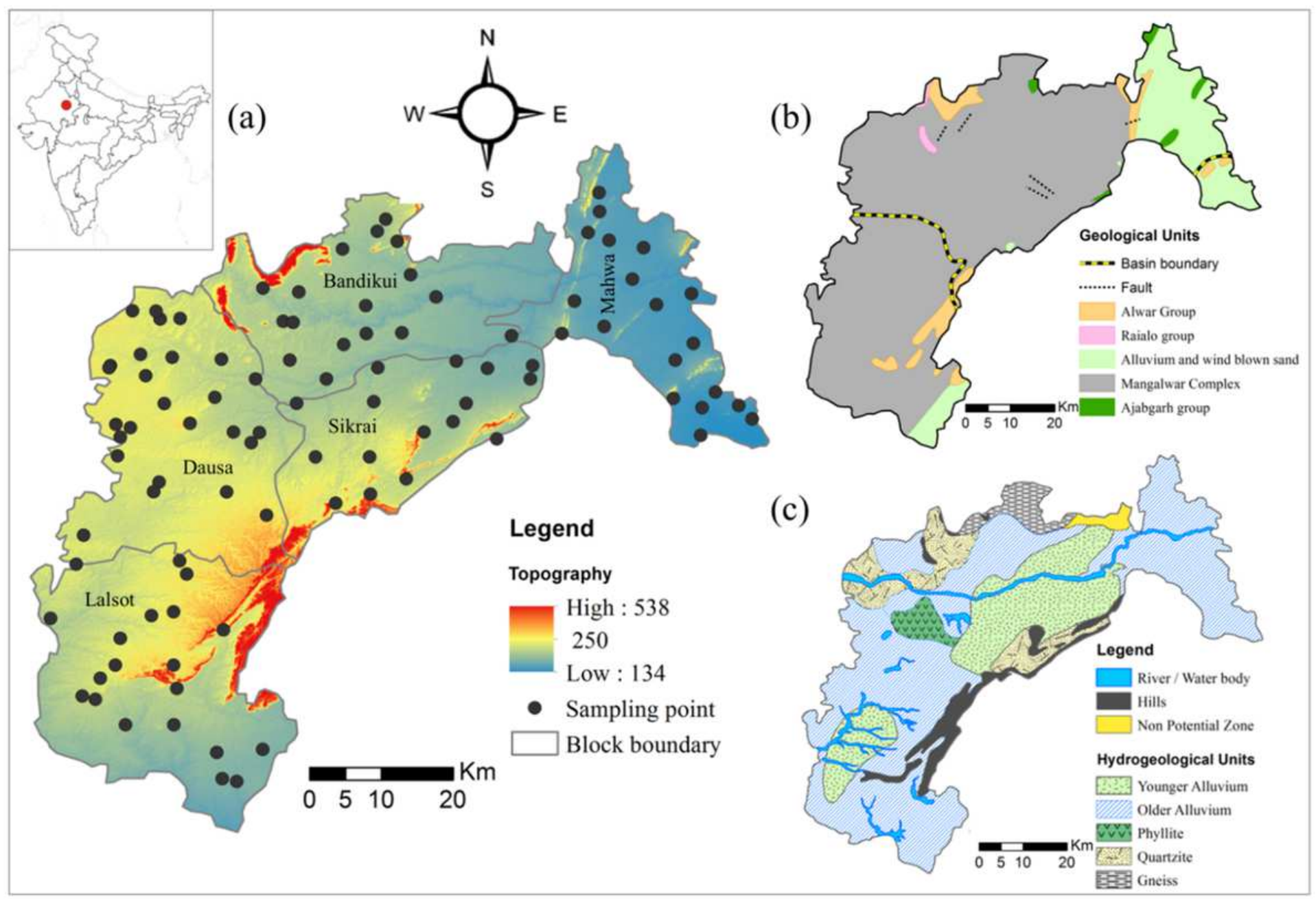

\section{Figure 1}

Showing the maps of (a) Topography in meters above mean sea level and the sampling location of Dausa district, Rajasthan, India, (b) regional geology, and (c) hydrogeology with the potential aquifers Note: The designations employed and the presentation of the material on this map do not imply the expression of any opinion whatsoever on the part of Research Square concerning the legal status of any country, territory, city or area or of its authorities, or concerning the delimitation of its frontiers or boundaries. This map has been provided by the authors. 

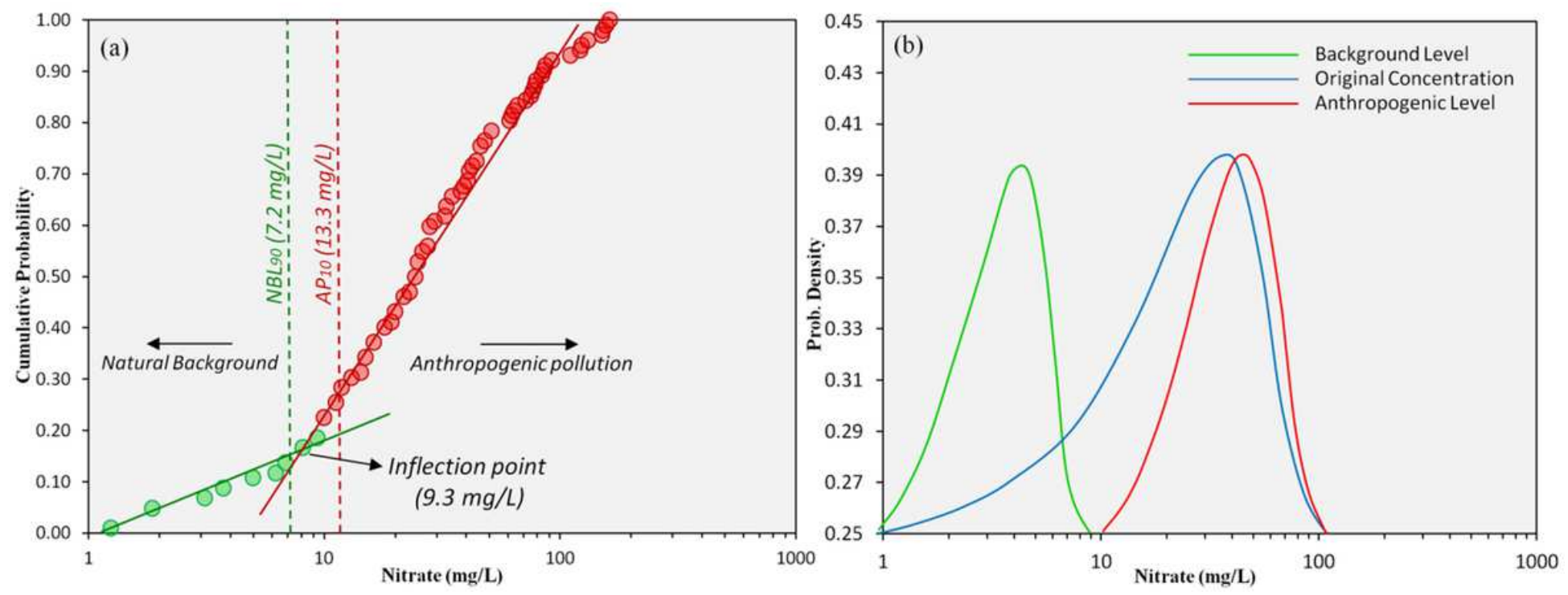

Figure 2

Showing (a) Cumulative probability plots of the NO3- concentration in groundwater on which two normal subpopulations events (estimated NBL; natural background level, and APL; anthropogenic level). In each plot, a single inflection point is observed on log-scale, and (b) Probability density curve of a distinct population of NO3- concentration in groundwaters 


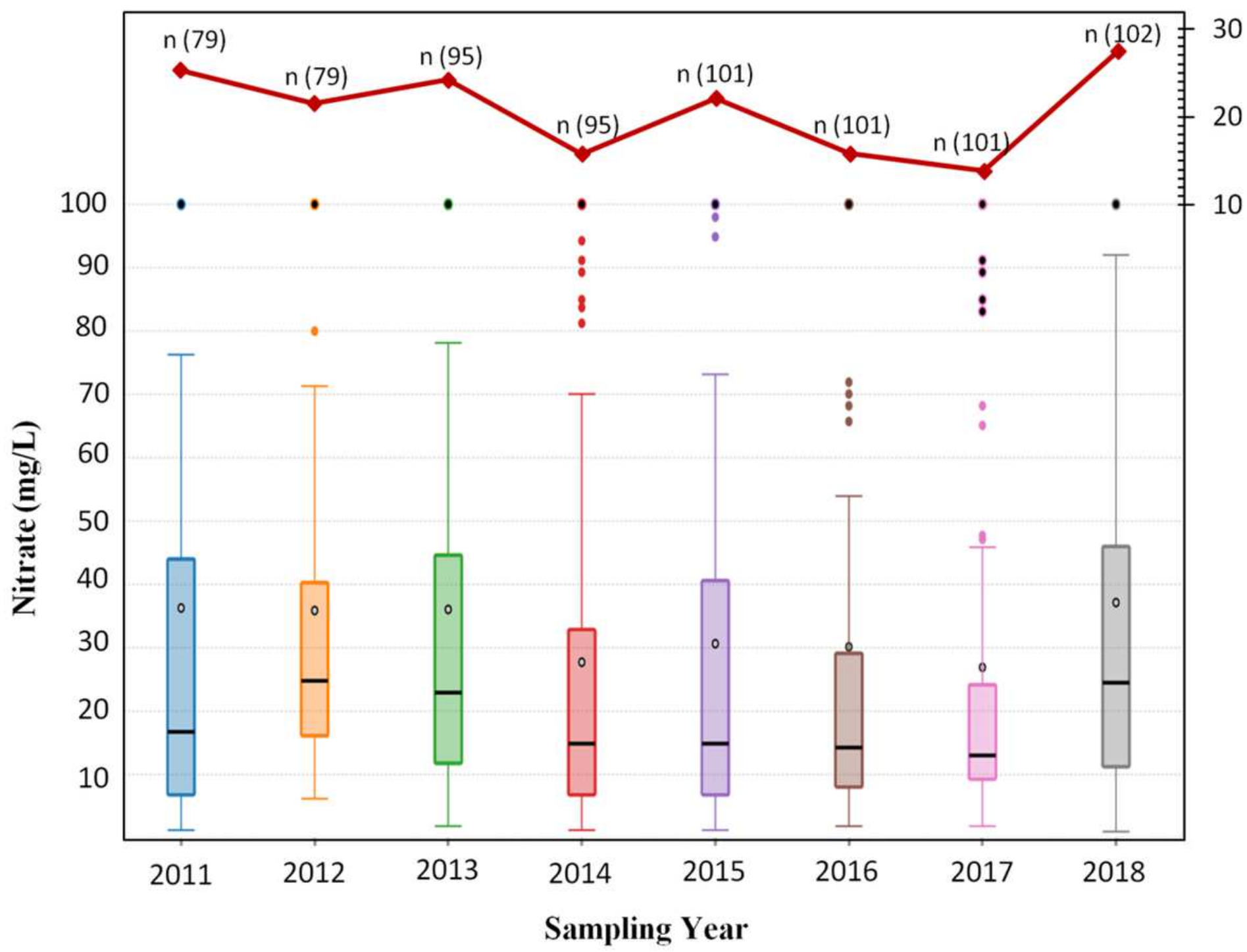

Figure 3

Showing the temporal changes of nitrate concentrations during 8 years (2011-2018) in groundwater of the study area. The red lines above the Box and Whisker plots illustrate the percentage of samples beyond the Indian drinking water standards $(45 \mathrm{mg} / \mathrm{L})$ and ' $n$ ' denoted as the number of groundwater samples 

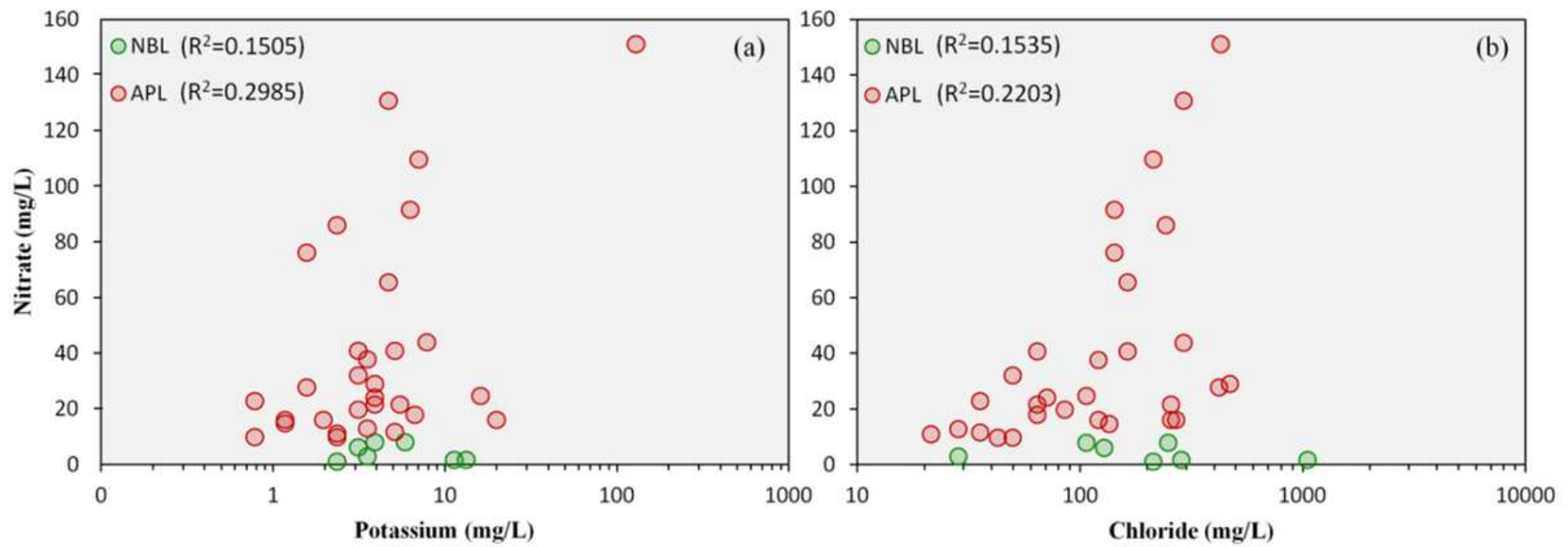

Figure 4

Scatter plots showing the relationship between (a) nitrate and potassium, and (b) nitrate and chloride 

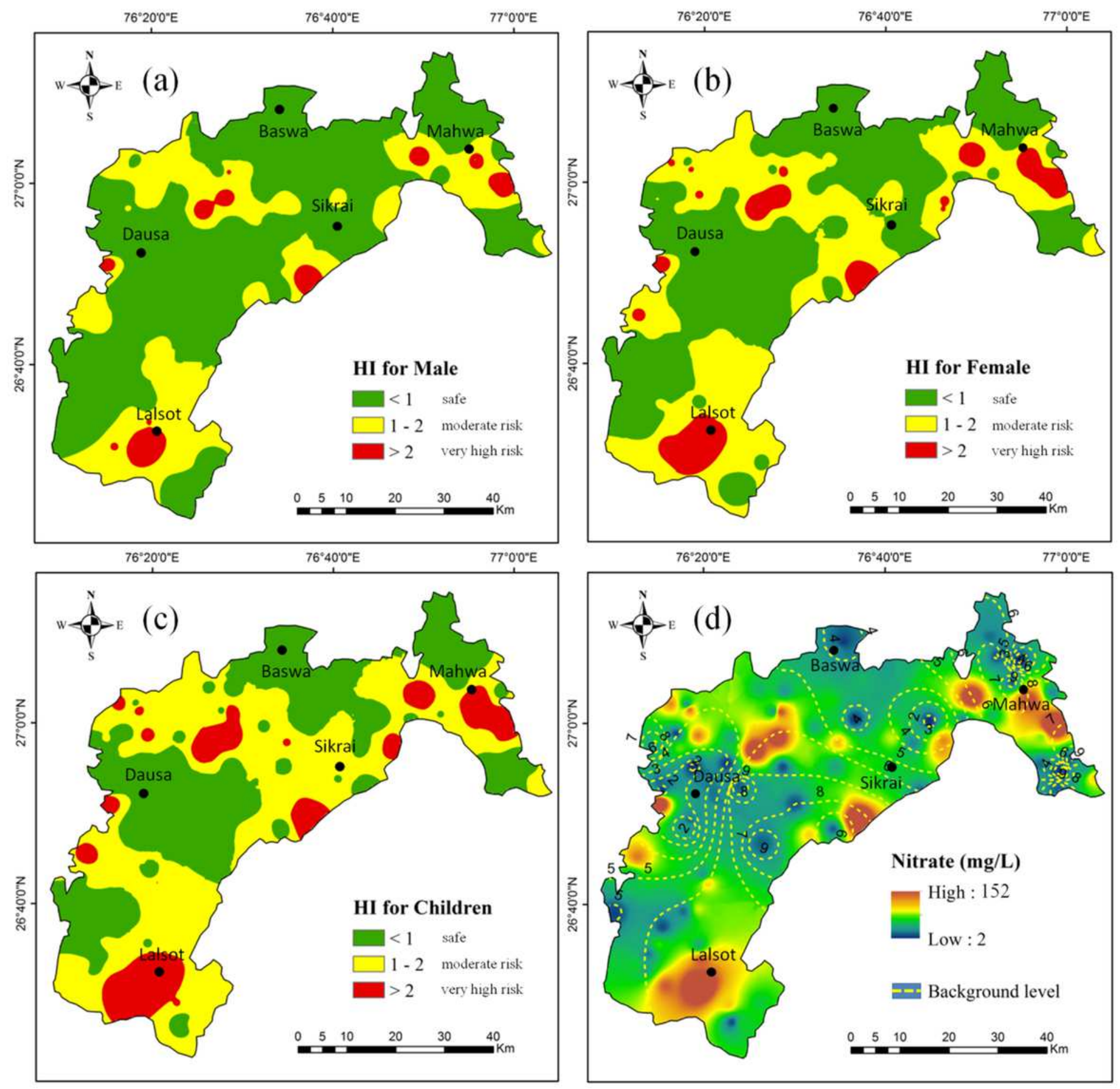

\section{Figure 5}

Showing spatial distribution of non-carcinogenic health risks for (a) Hazard Index (HI) of males, (b) Hazard Index (HI) of females, (c) Hazard Index (HI) of children in the study area, and (d) spatial distribution of nitrate concentration and its background concentrations with the contour lines Note: The designations employed and the presentation of the material on this map do not imply the expression of any opinion whatsoever on the part of Research Square concerning the legal status of any country, territory, city or area or of its authorities, or concerning the delimitation of its frontiers or boundaries. This map has been provided by the authors. 


\section{Supplementary Files}

This is a list of supplementary files associated with this preprint. Click to download.

- Supplementrymaterial.docx 